\title{
Diagnosis and treatment of hyperinsulinaemic hypoglycaemia and its implications for paediatric endocrinology
}

\author{
Huseyin Demirbilek', Sofia A. Rahman², Gonul Gulal Buyukyilmaz and Khalid Hussain ${ }^{3 *}$
}

\begin{abstract}
Glucose homeostasis requires appropriate and synchronous coordination of metabolic events and hormonal activities to keep plasma glucose concentrations in a narrow range of $3.5-5.5 \mathrm{mmol} / \mathrm{L}$. Insulin, the only glucose lowering hormone secreted from pancreatic $\beta$-cells, plays the key role in glucose homeostasis. Insulin release from pancreatic $\beta$-cells is mainly regulated by intracellular ATP-generating metabolic pathways. Hyperinsulinaemic hypoglycaemia $(H H)$, the most common cause of severe and persistent hypoglycaemia in neonates and children, is the inappropriate secretion of insulin which occurs despite low plasma glucose levels leading to severe and persistent hypoketotic hypoglycaemia. Mutations in 12 different key genes (ABCC8, KCNJ11, GLUD1, GCK, HADH, SLC16A1, UCP2, HNF4A, HNF1A, HK1, PGM1 and PMM2) constitute the underlying molecular mechanisms of congenital HH. Since insulin supressess ketogenesis, the alternative energy source to the brain, a prompt diagnosis and immediate management of $\mathrm{HH}$ is essential to avoid irreversible hypoglycaemic brain damage in children. Advances in molecular genetics, imaging methods $\left({ }^{18} \mathrm{~F}-\mathrm{DOPA}\right.$ PET-CT), medical therapy and surgical approach (laparoscopic and open pancreatectomy) have changed the management and improved the outcome of patients with $\mathrm{HH}$. This up to date review article provides a background to the diagnosis, molecular genetics, recent advances and therapeutic options in the field of $\mathrm{HH}$ in children.
\end{abstract}

Keywords: Hyperinsulinaemic hypoglycaemia, Congenital hyperinsulinaemia, Children, Diffuse, Focal, Sirolimus

\section{Background}

Hyperinsulinaemic hypoglycaemia $(\mathrm{HH})$, represents a group of clinically, genetically, and morphologically heterogeneous disorders characterized by inappropriate insulin secretion from pancreatic $\beta$-cells [1]. It is the most frequent cause of persistent hypoglycaemia in neonates and infants. Patients with $\mathrm{HH}$ have increased risk of permanent brain injury secondary to the metabolic actions of insulin. Insulin drives glucose into insulin sensitive tissues and inhibits endogenous glucose production through the inhibition of glycolysis and gluconeogenesis. The net effect is a decrease in the plasma glucose levels. Insulin also inhibits fatty acid release and ketone body synthesis which are the main alternative fuels of energy for brain neurons during states of low blood glucose [2]. Therefore, it is

\footnotetext{
* Correspondence: khussain@sidra.org; http://www.sidra.org

${ }^{3}$ Department of Paediatric Medicine Sidra Medical \& Research Center, OPC, C6-337, PO Box 26999, Doha, Qatar

Full list of author information is available at the end of the article
}

essential to make a rapid diagnosis of $\mathrm{HH}$ and immediately provide appropriate treatement of these patients to prevent the potentially associated neurological complications [3].

The clinical presentation of $\mathrm{HH}$ can vary and patients can present either with mild non-specific symptoms of hypoglycaemia (such as poor feeding, lethargy and irritability) or more severe symptoms (such as apnoea, seizures or even coma). HH can be congenital (known as congenital hyperinsulinaemic hypoglycaemia) or secondary to certain risk factors like birth asphyxia, intra-uterine growth retardation [4], maternal diabetes mellitus or associated with various developmental syndromes such as Beckwith-Wiedemann syndrome or metabolic conditions like congenital disorders of glycosylation (CDG) syndromes [5]. Most forms of $\mathrm{HH}$ present with fasting hypoglycaemia but in some cases the hypoglycaemia is provoked by protein/leucine loading or even straneous exercise [6-8]. Patients with HH may have an extremely 
variable clinical phenotype, from completely asymptomatic hypoglycaemia to pharmacologically responsive mild disease whilst in the severe cases, the disease is medically unresponsive and thus the patient requires surgical intervention $[1,9]$.

At the histological level, congenital forms of $\mathrm{HH}$ are classified into three subgroups: diffuse, focal, and atypical forms $[1,10,11]$. Differentiation of histological subtype is closely related to the management and outcome. Nevertheless, the clinical and biochemical fetaures do not differ and require further diagnostic tools. Recent advances in molecular genetics analysis and ${ }^{18} \mathrm{~F}$-fluoro-L-dihydroxyphenylalanine (18F-DOPA) PET/CT imaging have fundamentally changed the clinical approach to patients with $\mathrm{HH}[12,13]$.

Mutations in key genes which play a role in the regulation of insulin secretion, constitute the uderlying molecular genetics of congenital $\mathrm{HH}$. Until recently mutations in 9 different genes (ABCC8, KCNJ11, GLUD1, GCK, HADH, SLC16A1, UCP2, HNF4Aand HNF1A) that lead to dysregulated secretion of insulin had been described $[5,14,15]$. More recently, abnormalities in three new genes have been linked to $\mathrm{HH}$; hexokinase 1(HK1), phosphoglucomutase 1 (PGM1) and phosphomannosmutase 2 (PMM2) genes [16-19].

\section{Regulation of glucose homeostasis}

A balance between glucose production (exogenous and/or endogenous) and its utilization is the key to maintain a normal plasma glucose level. In healthy individuals, maintenance of a normal plasma glucose concentration requires a properly functioning hormonal system for integrating and modulating substrate mobilization, interconversion, and utilization. The main regulatory mechanisms are those involved in glucose mediated insulin secretion, glucose generation and utilization. Fatty acid mobilization and metabolism also play a crucial role in the maintenance of glucose homeostasis in infants and children. Beta oxidation of free fatty acids (FFAs) produces ketone bodies which can across the blood-brain barrier and provide the main alternative energy fuel for brain neurons. This would eventually reduce the requirement of glucose, particularly in the fasting state [20]. During fasting, children have a more rapid decline in plasma glucose concentration due to relatively less glycogen stores and a more rapid increase in the plasma concentration of ketone bodies than adults do [21]. In addition, infants are more capable of utilizing the ketones. Therefore children with $\mathrm{HH}$ are at a higher risk of brain damage compared to the adults [22, 23].

\section{Physiological mechanisms regulating insulin secretion from the pancreatic $\boldsymbol{\beta}$-cells}

The pancreatic $\beta$-cell possesses a unique signal transduction system, which links the metabolism of the fuel stimulus to initiate insulin secretion, the so called "stimulus-response coupling" [24]. Glucose is the most important fuel involved in the stimulus-response coupling mechanism. This stimulus response-coupling event is controlled by ATP-sensitive potassium channels $\left(\mathrm{K}_{\mathrm{ATP}}\right)$ located in the pancreatic $\beta$-cell membrane. Under normal physiological conditions, the metabolism of glucose is intricately linked to insulin secretion from pancreatic $\beta$-cells [25]. Glucose enters the $\beta$-cell through facilitative glucose transporters, particularly glucose transporter 2 (GLUT 2) and is converted to glucose-6-phosphate (G6P) by the enzyme glucokinase [26]. GLUT2 has high affinity for glucose which allows glucose transport in proportion to the plasma glucose concentrations [27]. Utilization of G6P through glycolysis generates high energy molecules; adenosine triphosphate (ATP) and increases the ratio of ATP/ADP (adenosine diphosphate) which closes the ATP-sensitive potassium channels $\left(\mathrm{K}_{\mathrm{ATP}}\right)$. $\mathrm{K}_{\mathrm{ATP}}$ channels are responsible for the regulation of intracellular and extracellular ion exchange and maintaining a steady state membrane potential. The closure of the $\mathrm{K}_{\mathrm{ATP}}$ channels results in depolarization of pancreatic $\beta$-cell membrane and activation of voltagegated calcium channels located in the $\beta$-cell membrane. Calcium enters into $\beta$-cell through these voltage-gated calcium channels and the increase in intracellular calcium triggers insulin secretory granule exocytosis (Fig. 1).

Glucokinase also plays a critical role in acting as a glucosensor, providing a link between the extracellular plasma glucose concentration and the metabolism of glucose in the $\beta$-cell [28]. When the plasma glucose concentration is increased, the activity of glucokinase is also increased, hence increasing insulin production and secretion from the $\beta$-cell (Fig. 1). Similarly, as the plasma glucose concentration decreases, serum insulin becomes undetectable when plasma glucose concentrations fall below $3 \mathrm{mmol} / \mathrm{l}[29,30]$.

\section{Transient (causes of) hyperinsulinaemic hypoglycaemia}

In babies with $\mathrm{HH}$ that resolves spontaneously either in a few days or weeks postpartum, transient $\mathrm{HH}$ is diagnosed. Transient HH can develop secondary to maternal diabetes mellitus, the use of intravenous dextrose given during labour, as well as intrauterine growth restriction (IUGR), small baby for gestational age (SGA) and perinatal asphyxia. Prolonged transient $\mathrm{HH}$ in IUGR and asphyxia babies have been reported to require treatment with diazoxide [31]. However, patients have also been noted to present with transient $\mathrm{HH}$ in the absence of the aforementioned risk factors [32]. The mechanism(s) behind this still remains unknown.

\section{Congenital hyperinsulinaemic hypoglycaemia}

The genetic basis of congenital $\mathrm{HH}$ involve defects in the pathways that regulate insulin release. These defects 


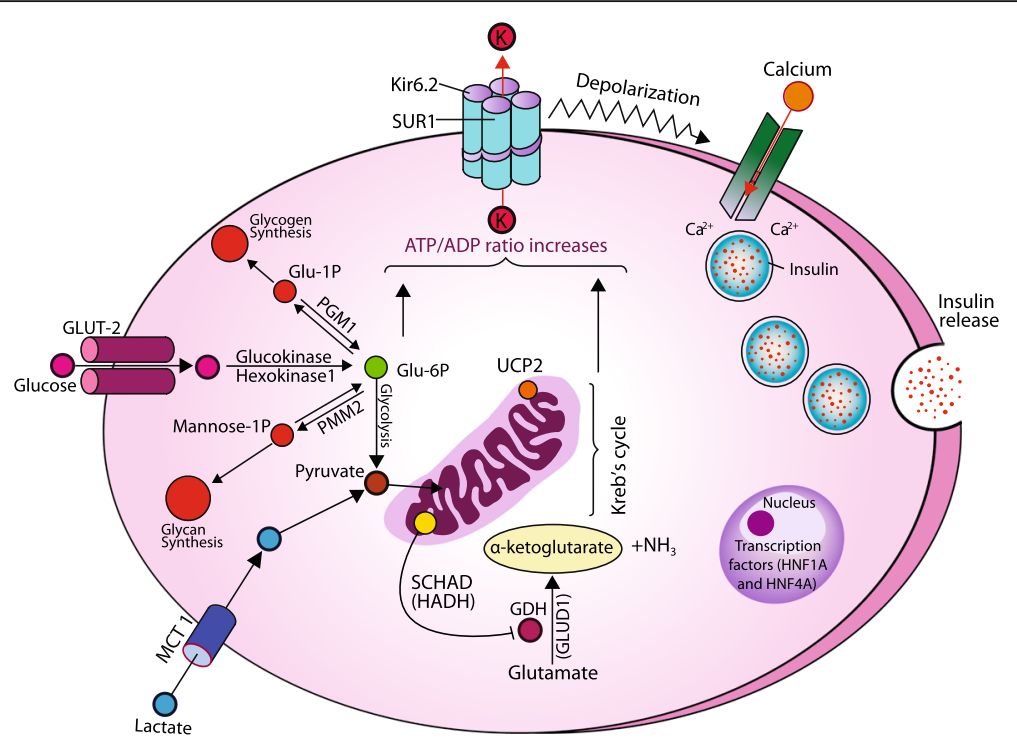

Fig. 1 Regulation of insulin release from pancreas $\beta$-cell and site of gene mutations involve in the genetics etiology of HH (SUR1: Sulphonyurea receptor 1; Kir 6.2: Inward rectifier potassium channel 6.2; K: Potassium; MCT1: Monocarboxlase transferase-1; Glu: glucose; P: Phosphorus; PGM1: Phosphoglucomutase 1; PMM2: Phosphomannose-mutase 2; UCP2: Mitochondrial uncoupling protein 2; $\mathrm{NH}_{3}$ : Ammonia; GDH: Glutamate dehydrogenase; GLUD1: Glutamate dehydrogenase 1 gene; HADH: Hydroxy-acyl-CoA dehydrogenase; HNF1A and 4A: Hepatocyte nuclear factor 1 and $4 ; \mathrm{Ca}^{+2}$ : Calcium

cause disturbances in the glucose-mediated insulin secretion processes and inappropriate release of insulin from the pancreatic $\beta$-cells. This therefore leads to severe hypoglycaemia in children. Currently, mutations in 12 genes have been reported to cause congenital $\mathrm{HH}$. However, the underlying molecular genetics etiology that causes congenital HH still remains unknown in about 50\% of patients. Table 1 outlines the transient and permanent causes of $\mathrm{HH}$.

\section{Genetics of Hyperinsulinaemic Hypoglycaemia Pancreatic $\beta$-cell $K_{\text {ATP }}$ channel defects}

The most prevalent and serious genetic cause of congenital $\mathrm{HH}$ is due to defects in the genes encoding the $\mathrm{K}_{\text {ATP }}$ channel (also known as channelopathies) [33, 34]. The $\mathrm{K}_{\mathrm{ATP}}$ channels are made up of two protein subunits; the sulphonlyurea receptor 1 (SUR1), which is encoded by the ATP Binding Cassette Subfamily C Member 8 $(A B C C 8)$ gene, and the inwardly rectifying potassium (Kir6.2), encoded by the Potassium Voltage-Gated Channel Subfamily J Member 11 (KCNJ11) gene. Both these genes are located on chrosome11p15.1. ABCC8 is 39 exons in length, whilst the KCNJ11 gene is only made up of 1 exon [35]. The $K_{\text {ATP }}$ channel complex is composed of four outer SUR1 subunits and four inner (poremaking) Kir6.2 proteins. The SUR1 component regulates the activity of the Kir6.2 proteins, in addition to a role in initiating a response and sensitivity to sulphonylurea drugs and $\mathrm{K}_{\mathrm{ATP}}$ channel opening drugs such as diazoxide [36, 37]. The inner Kir6.2 proteins allow influx of potassium ion concentrations across the membrane. Intracellular nucleotides such as ADP and ATP mediate the action of the $\mathrm{K}_{\text {ATP }}$ channel. A change in the ratio of ATP to ADP in the $\beta$-cell causes closure of the $K_{\text {ATP }}$ channel and triggers depolarisation of the cell membrane and activates the voltage-gated calcium channels [38]. This in turn causes insulin release through exocytosis and thus promotes lowering of plasma glucose [39].

Recessive inactivating (loss-of-function) $\mathrm{K}_{\mathrm{ATP}}$ channel gene mutations predominantly cause medically unresponsive diffuse congenital $\mathrm{HH}$, while, mild -even adult-onset$\mathrm{HH}$ have also been reported [5, 40-42]. Autosomal dominant inherited mutations usually cause milder forms of congenital $\mathrm{HH}$, whilst, medically unressponsive forms have also been reported $[43,44]$.

Another ten gene defects; GLUD1, HADH, GCK, SLC16A1, HNF1A, HNF4A, UCP2, HK1, PGM1and PMM2 have been proposed to cause congenital $\mathrm{HH}[19,45]$. Known as the metabolopathies due to mutations resulting in defects in the metabolic pathways that cause unregulated insulin release and associated hypoglycaemia.

\section{Glutamate dehydrogenase (GLUD1) mutations and Hyperinsulinism-hyperammonaemia syndrome (HI/HA)} During states of hypoglycaemia, alternative fuel sources are required. The Glutamate Dehydrogenase 1 (GLUD1) gene encodes for the mitochondrial enzyme; glutamate dehydrogenase $(\mathrm{GDH})$ which is essential in glutamate metabolism and has an important role in generating 
Table 1 Transient and permanent causes of hyperinsulinaemic hypoglycaemia

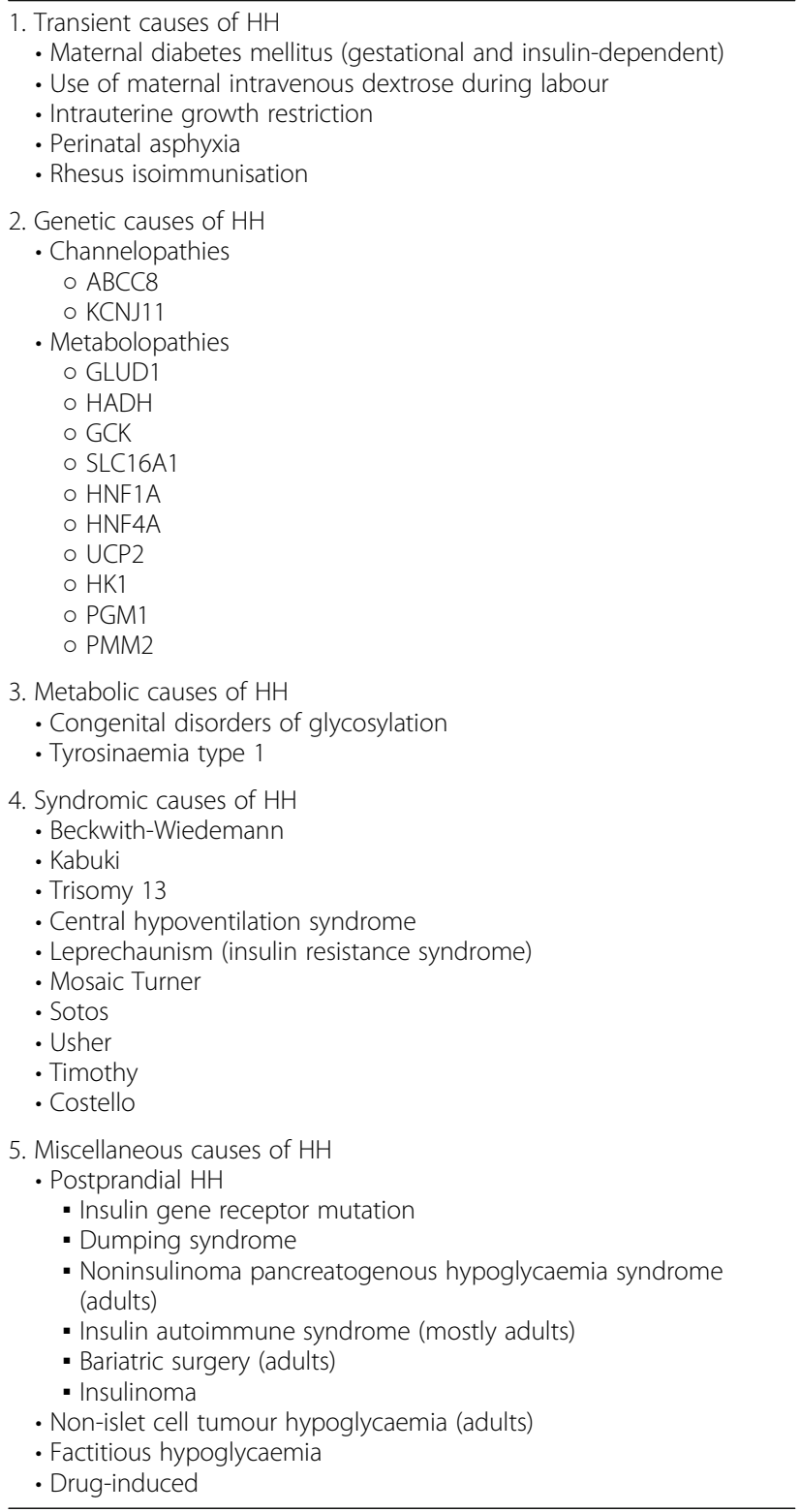

amino acids as fuel substitutes in the absence of glucose [6]. GDH appears to be sensitive to the amino acid leucine and nucleotide phosphate potential [7]. Both of these regulate GDH activity and thus stimulate amino acid-mediated insulin release. The GLUD1 mutations are associated with recurrent fasting and postprandial $\mathrm{HH}$ and is also known as the hyperinsulinism/hyperammonaemia (HI/HA) syndrome because of features that include high serum ammonia (usually two-to-threetimes the upper normal range) after consumption of a high protein meal. These infants usually are not lethargic/comatose as occurs in inborn errors of metabolism with hyperammonaemia, therefore, unless the serum ammonia level, the diagnosis of HI/HA syndrome may be missed. Urinary $\alpha$-ketoglutarate is elevated in patients with HI/HA syndrome [46].

GLUD1 mutations account for the most prevalent metabolopathic cause of congenital HH. Studies to date have identified mutations in exons 6, 7, 11 and 12 in the 13 exon gene to cause congenital $\mathrm{HH}[47,48]$. Although GLUD1 activating mutations occur mainly as de novo, some have reported patients presenting with autosomal dominant forms also [48, 49]. Since $\mathrm{K}_{\text {ATP }}$ channels are unaffected by the mutations, patients are medically controlled by the channel activator; diazoxide and are maintained on a low protein diet. Patients carrying GLUD1 mutations have been reported to be more sensitive in developing epileptic seizures irrespective of the severity and frequency of hypoglycaemia episodes. This has been attributed to the shift in the glutamate metabolism leading to a decline in the inhibitory neurotransmitter $\gamma$-aminobutyric acid (GABA) [50].

\section{Hydroxyacyl-CoA dehydrogenase (HADH) mutations and congenital $\mathrm{HH}$}

Hydroxyacyl-CoA dehydrogenase (HADH) or short chain L-3-hydroxyacyl-CoA dehydrogenase (SCHAD) is another mitochondrial enzyme that oxidises fatty acids to produce ATP. Although this gene is expressed in the liver, kidneys, muscle and heart, it is most abundant in the pancreatic islets [51]. The $H A D H$ gene has 8 exonic regions and mutations inherited in an autosomal recessive manner appears to reduce the enzymes inhibitory action on GDH [52-54]. Therefore, GLUD1 and $H A D H$ patients present similarly with protein sensitivity, although GLUD1 mutations also cause hyperammonemia. $H A D H$ gene mutations can lead either to severe neonatal congenital $\mathrm{HH}$ or to mild late-even adult-onset, protein-induced $\mathrm{HH}$ which is usually diazoxide responsive $[55,56]$. Although the clinical and etiological relevance are not clear, patient with $H A D H$ mutations may have elevated plasma concentrations of 3-hydroxy-butyryl-carnitine and urinary 3hydroxy-glutarate $[54,57]$.

\section{Glucokinase (GCK) mutations and congenital HH}

The GCK gene is 12 exons long and encodes the enzyme; glucokinase (GCK). GCK can be found in the pancreatic $\beta$-cells, liver and brain [58]. The GCK protein, catalyses glucose to G6P as substrate for glycolytic pathway which generates ATP, therefore, is essential in the glucosedependent insulin release. The GCK enzyme has high affinity to glucose, serving as a glucose-sensor in pancreatic $\beta$-cells. Dominant activating mutations in GCK cause alteration in the protein structure and functions from having a low affinity for glucose to having a high affinity and reduces the threshold for glucose-stimulated insulin release $[59,60]$. Variable clinical presentations occur ranging 
from neonatal severe $\mathrm{HH}$ to mild hypoglycaemia or even adult-onset asymptomatic or severe congenital $\mathrm{HH}$, majority of which respond to diazoxide whilst some require surgery [61-65].

\section{Exercise-induced Hyperinsulinaemic Hypoglycaemia}

The Solute Carrier Family 16 Member 1 (SLC16A1) gene encodes for the monocarboxylate transporter (MCT1). This protein has a role in transporting monocarboxylates such as pyruvate or lactate into the Krebs cycle to produce ATP and promote insulin release independently of glucose [66]. However, the low expression of this gene in the normal pancreatic $\beta$-cell suggests a physiological response to ensure against $\mathrm{HH}$. Autosomal dominant gainof-function mutations in SLC16A1 cause the expression of MCT1 in $\beta$-cells. This in turn leads to glycolysis-generated pyruvate to continually enter the Krebs cycle and induces inappropriate insulin secretion in states of low plasma glucose during anaerobic exercise [67]. Congenital $\mathrm{HH}$ due to these mutations is also known as exercise-induced $\mathrm{HH}$, since vigorous exercise stimulates hypoglycaemia. Diagnostically, SLC16A1 patients present with $\mathrm{HH}$ after a pyruvate load test [68]. Typically patients with exercise-induced $\mathrm{HH}$ develop hypoglycaemia following a bout of strenous exercise. Some patients may require therapy with diazoxide while others can be mananged with diet [8].

\section{Hepatocyte nuclear factor 1A\&4A (HNF1A\&4A) and congenital $\mathrm{HH}$}

The hepatocyte nuclear factors $1 \mathrm{~A}$ and $4 \mathrm{~A}$ genes (HNF1A/ $H N F 4 A$ ) encode for the HNF1- $a$ and HNF4- $a$ proteins, respectively. These are transcription factors for nuclear hormone receptors expressed in pancreatic $\beta$-cells and regulates glucose-dependent insulin secretion $[69,70]$. Inactivating mutations in $H N F 1 A$ and $H N F 4 A$ causes congenital $\mathrm{HH}$ in children and then maturity-onset diabetes of youth (MODY type 3 in HNF1A and type 1 in HNF4A) [71-73].

Hnfla null mice have unregulated insulin release, but the mechanism for this remains yet to be determined [74]. The exact role of HNF4 $\alpha$ in insulin regulation also is unknown since studies have found conflicting results using transgenic Hnf4a mouse models [69, 75]. Another potential explanation for this disease-causing mutation is the loss of peroxisome proliferators-activated receptor alpha (PPAR alpha; another nuclear factor). PPARo's role appears to direct fatty acids to the $\beta$-oxidation pathway and thus lead to hyperinsulinism during glucose depletion [76]. Moreover, in support of this, the Hnf4 alpha null mice have a decrease in PPAR $\alpha$ expression, whilst the Ppara knockout mice have been shown to develop fasting hypoglycaemia $[75,77]$.

Mutations in both HNF1A and HNF4A have been identified in macrosomic births and can range from mild transient to severe and permanent $\mathrm{HH}[5,42,71,78]$. Patients generally respond to diazoxide and $\mathrm{HH}$ resolves with age $[5,42,79,80]$. Mutation in the HNF4A gene have been reported in cases with $\mathrm{HH}$, increased level of glycogen in erythrocytes, elevated liver transaminases, and increased echogenicity on liver ultrasonography suggesting glycogenosis-like phenotype [81, 82]. Although, thought to be rare causes of congenital $\mathrm{HH}$, mutations in HNF1A and HNF4A have been reported at higher incidences in some series, particularly in those have diazoxide-responsive $\mathrm{HH}[79,83]$.

\section{Mutations in the uncoupling protein 2(UCP2) gene and congenital $\mathrm{HH}$}

Uncoupling protein 2 (UCP2) is mitochondrial carrier protein and encodes for the $U C P 2$ gene. Expressed in the pancreatic $\alpha$ - and $\beta$-cells, UCP2 inhibits glucose oxidation and activates glutamine oxidation by carrying four-carbon metabolites out of the mitochondria [84]. Inactivation of the UCP2 gene would therefore, promote glucose oxidation and thus cause $\mathrm{HH}$. Initially, it appeared that $U C P 2$ causing $\mathrm{HH}$ would resolve with age suggestive of a transient nature since the original cases were reported in patients of up to 6 years, however, new cases have emerged where $\mathrm{HH}$ continued beyond 10 years of age [85-87]. In a recent study, UCP2 mutations were reported for the underlying molecular genetics of $2.4 \%$ in a cohort of 211 patients with diazoxide-responsive congenital $\mathrm{HH}$ [87]. These patients developed hypoketotic-hypoglycaemia after a fairly good fasting tolerance, while some developed symptomatic hypoglycaemia following an oral glucose load. Rapid decline in plasma glucose and inappropriate insulin secretion following glucose load suggested that mutations in $U C P 2$ cause glucose-induced $\mathrm{HH}$ rather than fasting hypoglycaemia [87].

\section{Hexokinase 1 (HK1) gene mutations and congenital $\mathrm{HH}$} $H K 1$ is located on chromosome 10 and encodes the enzyme; hexokinase 1 (HK1). HK1 is one of the key enzymes involved in regulating glucose homeostasis. Normally, HK1 expression is silenced in the pancreatic $\beta$-cells. However recently, a report identified a dominant gain-of-function mutation in the $H K 1$ gene to cause $\mathrm{HH}$ in a family with "idiopathic hypoglycaemia of infancy" [16, 86].

\section{Phosphoglucomutase 1 (PGM1) gene mutations and congenital $\mathrm{HH}$}

Phosphoglucomutase 1 (PGM1) is involved in glycogen metabolism and a loss-of-function mutation in the PGM1 gene has been shown to be associated with hypoglycaemia [17]. Patients with these inactivating mutations have presented with fasting hyperketotic hypoglycaemia, as well as postprandial HH [18]. 


\section{Phosphomannomutase 2(PMM2) gene mutations and congenital $\mathrm{HH}$}

The phosphomannomutase 2 gene (PMM2) has recently been reported to cause $\mathrm{HH}$ as well as congenital polycystic kidney disease in 17 children from 11 unrelated families [19]. The group reported a promoter mutation (c.-167G > T) in the PMM2 gene in all affected patients. $P M M 2$ encodes for an enzyme in glycosylation, deglycosylation in pancreatic $\beta$-cells has been shown altered insulin secretion.

\section{Clinical presentation of hyperinsulinaemic hypoglycaemia}

$\mathrm{HH}$ can produce a variety of symptoms and effects, ranging from non-specific adrenergic symptoms (poor feeding, hunger, palpitation, sweating) to life-threatening neuroglycopenic symptoms arising from an inadequate supply of glucose to the brain neurons resulting in impairment of brain functions (seizures, unconsciousness, lethargy, coma, and even death). Delay in the diagnosis and inappropriate management from prolonged and recurring hypoglycaemia my result in permanent neurological sequelae. The neurological outcome is closely related to the severity, duration as well as the underlying mechanism for hypoglycaemia. In particular, disorders affecting both ketogenesis and hypoglycaemia have higher risk of permanent brain damage [88-90]. Newborns with congenital $\mathrm{HH}$ may be macrosomic due to intrauterine hyperinsulinaemia, however; the absence of macrosomia does not exclude $\mathrm{HH}$.

$\mathrm{HH}$ most commonly presents in the newborn, but it can also present during infancy, childhood and even adulthood $[40,87]$. The clinical presentation of hypoglycaemia is most severe in the newborn and may be quite subtle in the infancy and childhood periods [91]. However, some are not diagnosed until the first year or during childhood [91-93]. Even within the same family, the severity of disease can vary substantially. In a review of 114 cases, $65 \%$ presented as neonates, $28 \%$ as infants, and $7 \%$ during childhood [91]. Congenital HH caused by some genetic defects may be mild and in some cases resolves spontaneously. This was seen in a case series of infants with congenital $\mathrm{HH}$ but with normal $\mathrm{K}_{\mathrm{ATP}}$ channel and glutamate dehydrogenase function [94].

The $\mathrm{HH}$ due to recessive mutations in $A B C C 8 / K C N J 11$ genes is usually refractory to oral feeds and requires high concentrations of intravenous glucose to maintain normoglycaemia [3]. However, in the milder forms patients may be able to maintain normoglycaemia on oral feeds.

Hypertrophic cardiomyopathy and hepatomegaly (increased storage of glucose as glycogen) are observed in some patients with $\mathrm{HH}$. The mechanism of cardiomyopathy and hepatomegaly in these patients is unclear but might be related to the effect of foetal hyperinsulinaemia [3].

\section{Diagnosis and investigations of $\mathbf{H H}$}

The early diagnosis of $\mathrm{HH}$ is fundamentally important for preventing hypoglycaemic brain injury, hence, clinicians should always be aware of recognising and managing these patients. Any patient with recurrent or persistent hypoglycaemia can potentially have $\mathrm{HH}$, and this is the only cause of hypoglycaemia which persists despite continuous administration of glucose. A powerful clue to the dysregulated insulin secretion is the high intravenous glucose infusion rate required to maintain normoglycaemia. An intravenous glucose infusion rate of $>8 \mathrm{mg} / \mathrm{kg} / \mathrm{min}$ (normally is $4-6 \mathrm{mg} / \mathrm{kg} / \mathrm{min}$ ) is virtually diagnostic of $\mathrm{HH}[3]$.

In milder forms of $\mathrm{HH}$, it will be important to establish the duration of fasting and whether the hypoglycaemia is precipitated by meals (protein sensitivity) or by exercise.

In $\mathrm{HH}$, there is an inappropriate concentration of serum insulin/c-peptide for the low level of plasma glucose (spontaneous or provoked). The metabolic effect of inappropriate insulin secretion is reflected by the inappropriately low levels of serum ketone bodies and fatty acids during the hypoglycaemic episode. There is no correlation between the serum insulin concentration and the severity of the hypoglycaemia [95]. In some difficult cases, the diagnosis of $\mathrm{HH}$ should not be based on an isolated serum insulin/c-peptide concentration but on the clinical presentation and the biochemical profile of insulin action (low $\beta$-hydroxybutyrate and fatty acid concentrations). The diagnostic criteria for $\mathrm{HH}$ are summarised in Table 2.

An elevated serum ammonia concentration (appropriately collected and analysed) in a patient with $\mathrm{HH}$ is suggestive of the hyperinsulinism and hyperammonaemia (HI/HA) syndrome [47]. Raised plasma hydroxybutyrylcarnitine and urinary 3-hydroxyglutarate are diagnostic of a rare type of congenital $\mathrm{HH}$ (hydroxyacyl-Coenzyme A dehydrogenase (HADH) deficiency) [57].

Some types of $\mathrm{HH}$ are elicited only after provocation testing. For example in patients who have the $\mathrm{HI} / \mathrm{HA}$ syndrome (who have fasting as well as protein induced hypoglycaemia) protein/leucine loading precipitates hypoglycaemia [96]. The patients with exercise-induced $\mathrm{HH}$ will require a formal exercise test and or a pyruvate load to demonstrate post exercise induced $\mathrm{HH}[8,68]$. In some patients a positive glycaemic response (rise in the plasma glucose concentration of $>1.5 \mathrm{mmol} / \mathrm{L}$ ) following an intramuscular/intravenous injection of glucagon at the time of hypoglycaemia provides supportive evidence [97]. A glycaemic response to a subcutaneous dose of octreotide may also aid diagnosis. On the other hand as insulin suppresses the transcription of the insulin-like growth factor binding protein 1 (IGFBP-1) gene thereby IGFBP-1 synthesis serum levels of (IGFBP-1) is decreased in $\mathrm{HH}$ [98]. 
Table 2 Diagnostic criteria for patients with HH [1, 101]

\begin{tabular}{|c|c|}
\hline Diagnostic criteria & $\begin{array}{l}\text { - Plasma glucose }<3 \mathrm{mmol} / \mathrm{l} \text { with: } \\
\text { - Detectable serum insulin } \\
\text { - Detectable C-peptide } \\
\text { (In endogenous HH) } \\
\text { - Suppressed/low serum ketone bodies } \\
\text { - Suppressed/low serum fatty acids }\end{array}$ \\
\hline $\begin{array}{l}\text { Supportive evidences } \\
\text { (when diagnosis is in doubt } \\
\text { or difficult): }\end{array}$ & $\begin{array}{l}\text { - Glucose infusion rate }>8 \mathrm{mg} / \mathrm{kg} / \mathrm{min} \\
\text { - Positive glycaemic ( }>1.5 \mathrm{mmol} / \mathrm{L}) \\
\text { response to intramuscular/ intravenous } \\
\text { glucagon } \\
\text { - Positive glycaemic response to a } \\
\text { subcutaneous/intravenous dose of } \\
\text { octreotide } \\
\text { - Low serum levels of IGFBP1 [insulin } \\
\text { negatively regulates the expression of } \\
\text { IGFBP1] } \\
\text { - Suppressed branch chain (leucine, } \\
\text { isoleucine and valine) amino acids } \\
\text { - Provocation tests (leucine loading or } \\
\text { exercise testing) may be needed in } \\
\text { some patients } \\
\text { - Supressed/undetectable urine ketone } \\
\text { - Normal lactic acid } \\
\text { - Normal plasma hydroxybutyrylcarnitine } \\
\text { - Normal ammonia } \\
\text { - Appropriate counterregulatory hormone } \\
\text { response } \\
\text {-Cortisol > } 20 \text { mcg/dl (500 nmol/l) } \\
\text {-Growth hormone }>7 \text { ng/ml } \\
\text { In the neonatal period if the } \\
\text { hypoglycaemia persists for }>48 \text { h this } \\
\text { will require investigation }\end{array}$ \\
\hline
\end{tabular}

${ }^{\mathrm{a}}$ Elevated in $\mathrm{HH}$ due to $\mathrm{HADH}$ gene mutation, ${ }^{\mathrm{b}}$ Elevated in hyperinsulinism-hyperammonemia syndrome (HI-HA) due to GLUD1 gene mutation, 'Counterregulatory hormone response may be blunted in spontaneous, particularly recurring hypoglycaemia

\section{Hyperinsulinaemic hypoglycaemia management}

Patients with $\mathrm{HH}$ are at risk of severe brain injury, leading to short-term acute neurological symptoms (eg, seizure, lethargy, coma) and long-term neurological sequelae (eg, epilepsy, cognitive deficits, microcephaly) [99]. Hence, prompt diagnosis and immediate treatment is essential to avoid such complications.

Treatment of HH includes medical, surgical or sometimes combination therapies. Increasing and maintaining the plasma glucose concentration at a safe range (above $3.5 \mathrm{mmol} / \mathrm{L}$ ) is the goal of emergency therapy. The principal of long-term therapy is setting an equilibrium by inhibiting inappropriate insulin secretion and/or providing adequate glucose supply [100].

\section{Emergency management}

The goal of emergency treatment is to achieve normoglycemia immediately, keep plasma glucose levels at a safe range $(>3.5 \mathrm{mmol} / \mathrm{L})$ while the etiological investigations for differential diagnosis and long-term treatment planing are in progress.

\section{Parenteral glucose infusion}

At the time of hypoglycemia, once the critical sample has been obtained, if hypoglycemia is unresponsive to oral feeds, or the patient is unable to take an oral feed, a mini bolus of $2 \mathrm{mls} / \mathrm{kg} 10 \%$ glucose should be administered intravenously over $1 \mathrm{~min}$. To achieve normoglycemia and keep plasma glucose within the safe range, a continuous intravenous glucose infusion of $6-8 \mathrm{mg} / \mathrm{kg} /$ min should be commenced immediately. Patients with $\mathrm{HH}$ usually require a very high glucose infusion rate (GIR) to achieve and maintain normoglycaemia. Therefore, GIR might be adjusted according to consecutive plasma glucose measurements.

\section{Glucagon administration}

Glucagon induces glycogenolysis, gluconeogenesis, ketogenesis and lipolysis, and may be used in emergency situations where patients are unable to take oral feed and/or venous access is difficult to obtain $[101,102]$. The recommended single dose is between 0.5-1 mg [103]. Glucagon, in high doses, may cause rebound hypoglycemia due to a paradoxical increase in insulin secretion [104]. Glucagon can also be administered as continuous intravenous/subcutaneous infusion at a rate of $5-10 \mathrm{mcg} / \mathrm{kg} / \mathrm{h}$ for shortterm stabilization of plasma glucose as well as long-term non-surgical management of congenital $\mathrm{HH}$, in combination with octreotide [105, 106].

\section{Frequent feeding}

In infants, frequent high calorie carbohydrate feeds may reduce the frequency and severity of hypoglycaemic episodes. As these patients usually have food aversion, a percutaneous gastrostomy (PEG) may help to feed frequently and provide an opportunity to administer enteral boluses of high calorie-carbohydrate solutions [107, 108]. Uncooked cornstarch may help to decrease the hypoglycaemic episodes, particularly to improve fasting tolerance during a prolonged overnight fast in children over the age of one year.

\section{Long-term management}

The principles of long term management are inhibiting insulin secretion, thereby prevent recurrent hypoglycaemia episodes, provide an age appropriate fasting tolerance and avoid neurological symptoms associated to hypoglycemia.

\section{Diazoxide}

Diazoxide, the first-line drug for $\mathrm{HH}$, binds to and opens the SUR1 subunit of the $K_{\text {ATP }}$ channel [101, 102, 109, 110]. Diazoxide is usually effective in all forms of congenital $\mathrm{HH}$, except severe, neonatal-onset, recessive, and focal forms caused by mutations in the $A B C C 8$ and KCNJ11 [109]. Diazoxide needs an intact $\mathrm{K}_{\mathrm{ATP}}$ channel activity to work properly. Therefore, diazoxide responsiveness has 
been the key point for the molecular genetics analysis, differential diagnosis and management strategies of $\mathrm{HH}$. If a patient is unresponsive to the diazoxide, further genetic analysis for $A B C C 8 / K C N J 11$ and ${ }^{18} \mathrm{~F}$-DOPA-PET/CT scan must be performed to differentiate histological subtypes, focal or diffuse disease. The initial dose for diazoxide is usually $5 \mathrm{mg} / \mathrm{kg} /$ day, in 3 divided doses and then gradually can be increased up to maximum dose of $15-20 \mathrm{mg} / \mathrm{kg} /$ day [111]. The dose should be adjusted to achieve appropriate fasting tolerance for age and normoglycemia under a normal feeding plan. Fluid retention, hypertrichosis and feeding problems are the most common side effects of diazoxide. Therefore, especially in the newborns, when trying to reduce the risk of fluid retention, a thiazide diuretic, chlorothiazide $(7-10 \mathrm{mg} / \mathrm{kg} /$ day in 2 divided doses), should be administered with diazoxide. Hyperuricaemia, tachycardia and leukopenia, are other rare side effects [112] (Table 3). During follow up, if the diazoxide dose required to maintain normoglycaemia is lower than $5 \mathrm{mg} / \mathrm{kg} / \mathrm{day}$, consideration should be given to possibly withdrawing diazoxide in the hospital setting as some types of $\mathrm{HH}$ gradually resolve over time [113].

\section{Octreotide}

Octreotide, the second line drug of $\mathrm{HH}$, is an 8 amino acid synthetic somatostatin analogue that inhibits insulin secretion by binding to somatostatin receptor 2 and 5 (SSTR2 and SSTR5) [114]. Activation of SSTR5 decreases the insulin gene promoter activity and inhibits calcium mobilization and acetylcholine activity [115]. Somatostatin also inhibits the $\mathrm{K}_{\mathrm{ATP}}$ channel which results in reduced insulin secretion [102]. The initial dose of octreotide is $5 \mu \mathrm{g} / \mathrm{kg} /$ day given by subcutaneous injections at $6-8 \mathrm{~h}$ intervals. The recommended maximum dose is 30 $35 \mu \mathrm{g} / \mathrm{kg} /$ day. Long-term continuous, subcutaneous octreotide infusion with an insulin pump has also been

Table 3 Drugs for medical therapy of hyperinsulinaemic hypoglycaemia $[1,110,113]$

\begin{tabular}{|c|c|c|c|c|}
\hline & Route & Dose & Mode of action & Side effects \\
\hline \multicolumn{5}{|c|}{ Conventional medicines } \\
\hline Diazoxide & Oral & $\begin{array}{l}5-20 \mathrm{mg} / \mathrm{kg} / \mathrm{day}, \\
\text { in } 3 \text { divided doses }\end{array}$ & $\begin{array}{l}\text { Bind to SUR1 subunit of K KATP } \\
\text { channels, opens the channels } \\
\text { and inhibits insulin secretion } \\
\text { Requires an intact } K_{\text {ATP }} \text { channel } \\
\text { activity to work properly }\end{array}$ & $\begin{array}{l}\text { Common: Water and salt retention, } \\
\text { hypertrichosis, loss of appetite } \\
\text { Rare: Cardiac failure, hyperuricaemia, } \\
\text { blood dyscrasias (bone marrow } \\
\text { suppression, anaemia, eosinophilia etc.), } \\
\text { paradoxical hypoglycaemia }\end{array}$ \\
\hline Chlorothiazide & Oral & $\begin{array}{l}\text { 7-10 mg/kg/day, } \\
\text { in } 2 \text { divided doses }\end{array}$ & $\begin{array}{l}\text { Prevents fluid retention, } \\
\text { synergistic effects with } \\
\text { diazoxide on K KaTP channels to } \\
\text { inhibit insulin secretion }\end{array}$ & Hyponatraemia, hypokalaemia \\
\hline Nifedipine & Oral & $\begin{array}{l}0.25-2.5 \mathrm{mg} / \mathrm{kg} / \text { day, } \\
\text { in } 2-3 \text { divided doses }\end{array}$ & $\begin{array}{l}\text { Inhibits Ca-channels of the } \\
\beta \text {-cell membrane }\end{array}$ & Hypotension \\
\hline Octreotide & S.C & $\begin{array}{l}5-35 \mu \mathrm{g} / \mathrm{kg} / \mathrm{day} \text {, } \\
\text { divided to } 3-4 \text { doses } \\
\text { or continuous } \\
\text { subcutaneous infusion }\end{array}$ & $\begin{array}{l}\text { Activation of SSTR-2 and } \\
\text { SSTR-5 inhibits calcium } \\
\text { mobilization and acetylcholine } \\
\text { activity, and decreases insulin } \\
\text { gene promoter activity, } \\
\text { reduces insulin biosynthesis } \\
\text { and insulin secretion. }\end{array}$ & $\begin{array}{l}\text { Acute: Anorexia, nausea, abdominal } \\
\text { discomfort, diarrhoea, drug induced } \\
\text { hepatitis, elevated liver enzyme, } \\
\text { long QT syndrome, tachyphylaxis, } \\
\text { necrotizing enterocolitis } \\
\text { Long-term: Decreases intestinal motility, } \\
\text { bile sludge and gallstone, suppression } \\
\text { of pituitary hormones (Growth } \\
\text { hormone, TSH) }\end{array}$ \\
\hline Glucagon & $\begin{array}{l}\text { s.c/i.m bolus or s.c/i.v } \\
\text { infusion }\end{array}$ & $\begin{array}{l}0.02 \mathrm{mg} / \mathrm{kg} / \mathrm{dose} \text { or } \\
5-10 \mu \mathrm{g} / \mathrm{kg} / \mathrm{h} \text { infusion }\end{array}$ & $\begin{array}{l}\text { G-protein coupled activation of } \\
\text { adenylate cyclase, increases } \\
\text { cAMP, Induces glycogenolysis } \\
\text { and gluconeogenesis }\end{array}$ & $\begin{array}{l}\text { Nausea, vomiting, skin rash and } \\
\text { rebound hypoglycaemia in high doses } \\
(>20 \mu \mathrm{g} / \mathrm{kg} / \mathrm{h}) \text { due to paradoxical } \\
\text { activation of insulin secretion }\end{array}$ \\
\hline
\end{tabular}

New medicines

Rapamycin Oral

(sirolimus, everolimus)

Octreotide

LAR/ Lanreotide
An initial dose of

$1 \mathrm{mg} / \mathrm{m} 2$ per day may require dose adjustment according to blood sirolimus concentration usually to keep between 5 and $15 \mathrm{ng} / \mathrm{ml}$

Total 4 weekly dose of octreotide given every 4 weekly or $15-60 \mathrm{mg} /$ every 4 weekly
mTOR inhibitor. Inhibits insulin release and $\beta$-cell proliferation through different mechanism which have not been clarified yet

These long acting somatostatin analogues have similar effects as daily multidose octreotide.
Immune suppression, mucositis, hyperlipidemia, elevation of liver enzyme, thrombocytosis, impaired immune response to $B C G$ vaccine

Similar to daily multiple injection octreotide. However, long-term follow up is not known yet 
reported as a feasible alternative to surgery for patients with monoallelic $\mathrm{K}_{\mathrm{ATP}}$-channel mutations [116]. The first response to octreotide administration is usually hyperglycaemia followed by a blunted effect within 24-48 h (tachyphylaxis), thereby, dose adjustment may be required to keep plasma glucose level at normoglycaemic levels [101, 117, 118]. Tachyphylaxis, necrotizing enterocolitis, anorexia, nausea, abdominal pain, diarrhoea, gall bladder pathologies, elevation of liver transaminases, pituitary hormone suppression, long QT syndrome and arrest in linear growth are the reported side effects in patients treated with octreotide [110, 119-126] (Table 3). However, in recent studies evaluating the long-term effects of octreotide therapy in patients with congenital $\mathrm{HH}$ the effect of octreotide on linear growth have been found to be of no clinical relevance [110, 121].

\section{Long-acting somatostatin analogs}

Recently long-acting somatostatin analogs have been an effective option in the management of congenital $\mathrm{HH}$. Octreotide long-acting release (LAR) is formulated with biodegradable microspheres [127]. This formulation provides the advantage of administration every 28 days. Lanreotide is also a synthetic octapeptide and it is recommended to inject every 28 days. LAR-octreotide and lanreotide have been successfully used in children with congenital HH [110, 128-132]. The opportunity to administer LAR once in every 4 week not only increases treatment compliance but also increases quality of life (QoL) [128]. Therefore, increasing experiences with LAR may improve the treatment compliance and most favorable long-term outcome of patients with congenital $\mathrm{HH}$.

\section{Nifedipine}

Nifedipine, a calcium channel blocker, inhibits insulin secretion by inactivating the voltage-gated calcium channels [133]. Recommended dose is $0.25-2.5 \mathrm{mg} / \mathrm{kg} / \mathrm{day}$ divided into 2-3 doses [102]. Hypotension is an uncommon side-effect [102] especially at doses above $0.5 \mathrm{mg} /$ kg/day [134] (Table 3). Although, in many case reports nifedipine treatment has shown to have a favourable effect on $\mathrm{HH}$, in a recent study exclusively investigating its use in $\mathrm{HH}$ due to mutations in the $A B C C 8$ gene, $\mathrm{HH}$ has shown not responded nifedipine therapy [135]. It is, therefore, suggested that, mutations in the $\mathrm{K}_{\mathrm{ATP}}$ channel genes might render the L-type calcium channel ineffective to therapy with nifedipine [135-139].

\section{New and potential future therapies}

A group of patients with diffuse and focal disease are unresponsive to conventional medical therapies, both diazoxide and octreotide. Surgery has been the treatment option for this patients. Nevertheless, after surgery recurrent $\mathrm{HH}$ can continue or may be complicated with diabetes mellitus or exocrine pancreas insufficiency. This group of patients are area of interest for clinicians for trial of novel therapeutic options to better improve their short- and long-term outcome.

\section{Sirolimus}

Sirolimus is a mammalian target of rapamycin (mTOR) inhibitor. mTOR is a serine and threonine protein kinase and regulates cellular growth by stimulating protein synthesis by increasing mRNA translation initiation and the capacity of the ribosomal protein machinery [140]. The mechanism of action for mTOR inhibitors in $\mathrm{HH}$ has not been fully elucidated. However it is reported that there is constitutive activation and overexpression of p-mTOR on the plasmalemmal aspect of the acinar cells, and activation on the plasmalemmal aspect of the ductal cells in the diffuse variant of congenital $\mathrm{HH}$ [141].

A number of autocrine growth factors like IGF-I, vascular endothelial growth factor (VEGF), and epidermal growth factor receptor (ErbB), as well as glucose, fatty acids, and amino acids activate mTOR pathway. Upregulation of mTOR leads increased insulin production in the pancreatic $\beta$-cells [142]. Conversely, inhibition of mTOR with rapamycin inhibits insulin secretion as well as $\beta$-cell growth [143]. Sirolimus can also induces $\beta$-cell apoptosis and promotes insulin resistance. Furthermore, mTORC1 inhibits PPAR $\alpha$-mediated expression of ketogenic genes thereby ketone body synthesis, therefore, down-regulation of the mTOR pathway may restores ketogenesis which inturn reduces the risk of brain injury in patients with $\mathrm{HH}$ [21]. Recently, it has been reported that sirolimus is effective and safe for the severe, diazoxide unresponsive diffuse congenital $\mathrm{HH}$ with no major side effects [144]. Following the first experience, several number of case reports indicating the successful use of sirolimus have been published [145-149].

Although the optimal therapeutic blood levels for sirolimus in congenital $\mathrm{HH}$ patient have not been determined, ranges previously defined for the use of renal transplant patients, $5-15 \mathrm{ng} / \mathrm{ml}$ is advised [144]. The most reported adverse effects are stomatitis, increased risk of infection, immunosuppression, renal dysfunction, fatigue, pneumonitis and increased serum aminotransferase or lipid levels [150]. Since, sirolimus have severe side effects, particularly due to risk arising from immunesuppression, patients under sirolimus therapy, should be closely monitored for adverse effects. Despite limited clinical experience in CHI, mTOR inhibitors are thought to be a good option for selected patients who do not respond to diazoxide or octreotide. However, in a recent report evaluating the efficacy of sirolimus in 10 patients with diazoxide unresponsive congenital $\mathrm{HH}, \mathrm{mTOR}$ inhibition has shown to achieve euglycemia, improve fasting tolerance, and reduced requirement for medical therapy in only three 
patients (30\%) with certain side effects [151]. In addition, pancreatic tissue from two patients who did not respond to sirolimus showed no reduction in cell proliferation, further suggesting that mTOR signaling did not downregulate proliferation in the pancreas of patients with congenital HH [151]. Nevertheless, as recommended the last option prior to surgery, trying sirolimus before performing surgical therapy may help avoiding from much more severe and lifelong complications of surgery. Even so, this does not eliminate the requirement for further insights into identifying the long-term adverse effects and efficacy of mTOR inhibitors.

\section{GLP-1 receptor antagonist: Exendin (9-39)}

Glucagon-like peptide-1 (GLP-1), released after a meal, is an incretin hormone produced in enteroendocrine Lcells of the intestine in response to ingested nutrients [152]. GLP-1 stimulates insulin secretion by binding to a guanine nucleotide binding protein-coupled receptor [153], resulting in the activation of adenylate cyclase and generation of cAMP [154]. GLP-1 stimulates insulin secretion by both protein kinase A-dependent and -independent mechanisms [155] and also inhibits glucagon secretion, hepatic glucose production, gastric emptying, and appetite. Exendin-(9-39) is a specific GLP-1 receptor antagonist in mice and humans [156, 157]. A previous study in Sur-1 knock-out mouse showed that Exendin(9-39) raised fasting plasma glucose levels by decreasing cAMP levels and insulin secretion [158]. Another study demonstrated that exendin-(9-39) prevents hypoglycemia and maintains stability of plasma glucose during a prolonged fast in individuals with $\mathrm{K}_{\mathrm{ATP}}-\mathrm{HI}$ [159]. These promising results point to the GLP-1 receptor as a therapeutic target for $\mathrm{K}_{\mathrm{ATP}}-\mathrm{HI}$.

\section{Use of chaperones}

Mutations in $A B C C 8$ encoding SUR1 subunit of the $\mathrm{K}_{\text {АTP }}$ channel inhibit trafficking of channel proteins from the endoplasmic reticulum to the cell surface, thereby, preventing the channel function. Chaperones are small molecules that correct the trafficking of $\mathrm{K}_{\mathrm{ATP}}$-channels. In previous in-vitro studies, sulfonylureas and carbamazepine, have been shown to correct channel trafficking defects in the transmembrane domains 0 and 1 (TMD0, TMD1) mutations of $A B C C 8[160,161]$.

In a recent study, 13 novel SUR1 mutations that cause channel trafficking defects, were pharmacologically rescued using glibenclamide and carbamazepine [162]. In the cross-linking experiments it was shown that while $\mathrm{K}_{\mathrm{ATP}}$ channel inhibitors promoted interactions between the $\mathrm{N}$ terminus of Kir6.2 and SUR1, channel openers did not. This was suggested that to correct the channel biogenesis and trafficking defects, $\mathrm{K}_{\mathrm{ATP}}$ channel inhibitors enhance interactions between Kir6.2 and SUR1 subunits [162].
Furthermore, in the functional studies most mutant channels rescued to the cell surface using chaperons exhibited WT-like sensitivity to ATP, MgADP, and diazoxide. After rescuing the trafficking defect diazoxide had effectively recovered the channel function [162]. Although it is still at experimental level and requires further investigations, using chaperones for correction of channel trafficking would perhaps improve diazoxide responsiveness in congenital $\mathrm{HH}$ due to $A B C C 8$ mutations.

\section{Ketogenic diet}

During the suckling period, ketone bodies constitute a higher proportion of fuel for energy for the immature brain. Upon brain maturation and weaning, blood levels of ketone bodies decrease and glucose becomes the main energy for the mature brain [163]. Increase in ketone bodies concentration promotes the oxidation rate in the brain $[164,165]$. For this reason they have been used as therapy against refractory epilepsy and in experimental models of ischemia and excitotoxicity [166]. HH induces severe neuroglycopenia and also inhibits gluconeogenesis, glycogenolysis, lipolysis, and eventually fatty acid oxidation which result in inapproriate ketone synthesis. Therefore, neurological risk of hypoglycaemia further increases because of lack of ketones. In a recent study ketogenic diet was administered in a child with drugresistant congenital HH due to a spontaneous GCK activating mutation for 2 years. After the first six months, the patient had become free of epileptic seizures, with normalization of EEG, and showed a marked recovery in psychological development and quality of life [167]. Although requires further evidence, these findings suggested that ketogenic diet could have a neuroprotective effect despite persistence of neuroglycopenia and it can be used in selected cases of $\mathrm{HH}$.

\section{Histologic subtypes of congenital $\mathrm{HH}$}

At the histologic level, there are three forms of congenital $\mathrm{HH}$; focal, diffuse, and atypical disease (Fig. 2). Differentiation of histologic subtypes is essential for the success of surgery.

\section{Focal form}

The abnormal pancreatic $\beta$-cells are localised to a specific location in pancreas. Focal pancreatic lesions are generally 2-10 $\mathrm{mm}$ in size and appear as small regions of islet adenomatosis (nodular hyperplasia of islet-like cell clusters, including ductuloinsular complexes, Fig. 2d) [1]. Islet cells of particular lesion have large cytoplasm with dispersed abnormal nuclei of irregular and angular shape [168]. Focal disease is mostly sporadic and is associated with a paternally inherited $\mathrm{K}_{\mathrm{ATP}}$ channel mutation and the loss of the corresponding maternal allele in the focal area [169]. This promotes $\beta$-cell proliferation by 


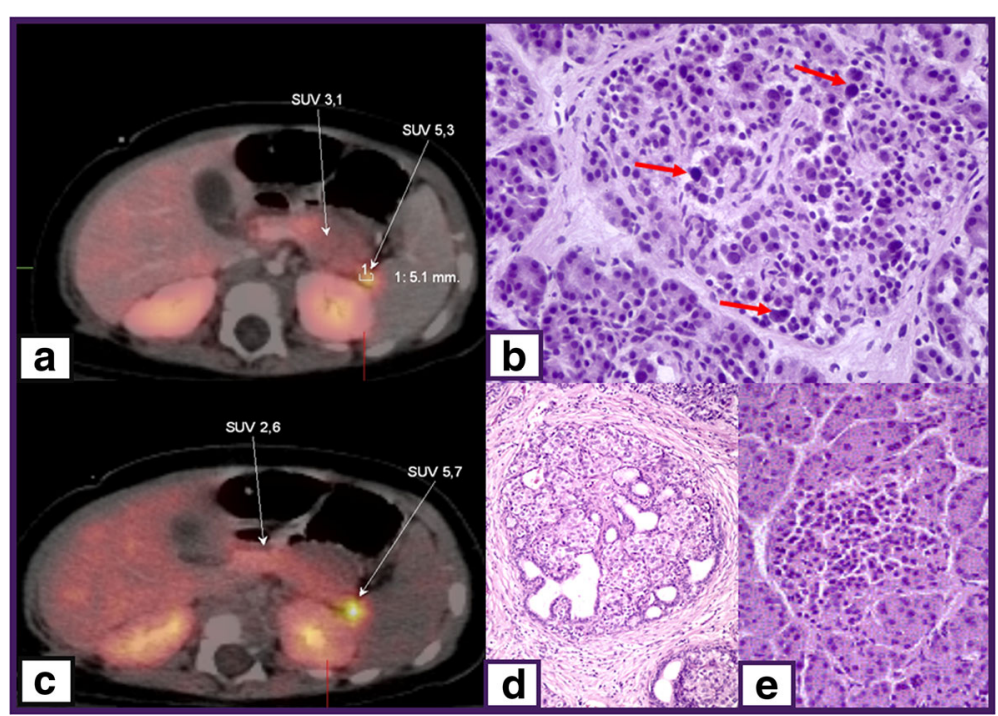

Fig. $2{ }^{18} \mathrm{~F}$-DOPA-PET/CT scan images of focal CHI (a and $\mathbf{c}$ ), histological figure of diffuse (b) and focal (d) disease and normal pancreas islet cell (e). SUV 5.3 and SUV 5.7 indicate focal uptake of ${ }^{18} \mathrm{~F}$-DOPA, red arrows show large nuclei of $\beta$-cell in diffuse disease

inducing the expression of insulin-like growth factor 2, inhibiting the tumor suppressor genes H19 and cyclindependent kinase inhibitor 1C (CDKN1C) [170]. The Fluorine-18 dihydroxyphenylalanine-positron emission tomography $\left({ }^{18} \mathrm{~F}-\mathrm{DOPA}-\mathrm{PET}\right)$ scanning can help to localize focal lesion. The principle of ${ }^{18} \mathrm{~F}$-DOPA-PET scan is based on the tissue uptake of L-DOPA. Pancreatic islets are able to uptake L-DOPA and convert it to dopamine through DOPA decarboxylase. The uptake of the positron emitting tracer ${ }^{18} \mathrm{~F}$-DOPA-PET is increased in $\beta$-cells with a high rate of insulin synthesis and secretion compared to unaffected areas (Fig. 2a and c). The sensitivity for detecting focal lesions varies between 88 and $94 \%$ with an accuracy of $100 \%$ [171]. Intraoperative and postoperative diagnosis of focal congenital $\mathrm{HH}$ is based on the presence of adenomatous hyperplasia of $\beta$-cells within the focal lesion [172].

\section{Diffuse form}

The diffuse form accounts for $60-70 \%$ of all congenital $\mathrm{HH}$ cases, and affects all pancreatic $\beta$-cells. Morphology of the islets of Langerhans shows the presence of $\beta$-cells with abnormally large nuclei (Fig. 2b) [173]. Patients with diffuse congenital $\mathrm{HH}$ either have a homozygous recessive or a compound heterozygous mutation in $\mathrm{K}_{\text {АTP }}$ channel genes [174]. Patients are usually unresponsive to the medical therapy and require a near-total pancreatectomy (95-98\% removal).

\section{Atypical forms}

If the pancreatic histology neither fits the focal nor diffuse congenital $\mathrm{HH}$ category, this can be defined as atypical form. In these atypical forms some islets show signs of hyperplasia but others appear normal. A previous study reported that some patients with congenital $\mathrm{HH}$ have morphological mosaicism including coexistence of two types of islet: large islets with cytoplasm-rich cells and occasional enlarged nuclei and shrunken islets with -cells exhibiting little cytoplasm and small nuclei [170].

\section{Surgical therapy}

Prior to surgery, it is very important to distinguish between diffuse and focal subtypes and localize the lesion in case of focal disease. Recent advances in the molecular genetics of congenital $\mathrm{HH}$ and imaging with ${ }^{18} \mathrm{~F}$-DOPAPET/CT scan, have largely contributed to short- and longterm successful management of patients, particularly those with focal disease [173]. While diffuse disease exhibits a diffuse uptake on the ${ }^{18} \mathrm{~F}$-DOPA-PET/CT scan, focal form shows a focal uptake (Fig. 2) [175, 176]. Also intraoperative frozen sections are essential both to confirm the diagnosis made based on imaging and to determine whether the suspected area effectively corresponds to a focal lesion and is completely resected [177].

\section{Surgery of focal disease}

Detection of paternally inherited mutations in $\mathrm{K}_{\text {АTP }}$ channel genes and localization of lesion using imaging with ${ }^{18} \mathrm{~F}$-DOPA-PET/CT scan provide possibility of completely cure of the disease by limited lesionectomy/partial pancreatectomy, with few or no surgical complications $[41,178,179]$. In proximal lesions in the head and neck of 


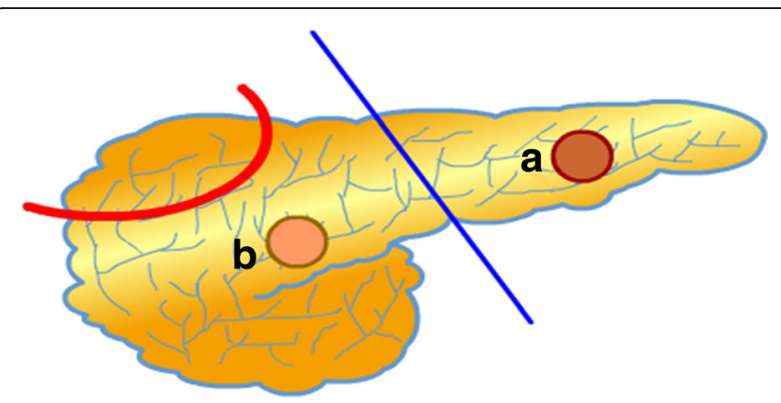

Fig. 3 A schematic appearance of pancreatectomy methods for surgery of congenital $\mathrm{HH}$. While for a focal case only limited lesionectomy (a and $\mathbf{b}$ ) provide cure without any postsurgical complication, in case of diffuse disease, extensive excision (laparoscopic or open) of a certain part of pancreas may result in continuum of the $\mathrm{HH}$ or developing exocrine and endocrine pancreas insufficiency

the pancreas, open resection of the lesion with a small rim of surrounding normal pancreatic tissue is carried out and pancreaticojejunostomy is performed to allow drainage of the distal pancreas. Laparascopic distal pancreatectomy is the surgical option for distal lesions (Fig. 3,) [9].

\section{Surgery for diffuse and atypical disease}

Patients with diffuse and atypical disease that are unresponsive to medical treatment usually require extensive surgery (subtotal- or near-total pancreatectomy). Although this might alleviate the recurrence risk of hypoglycaemia, this procedure caries a high risk of developing pancreatic exocrine insufficiency and diabetes which requires lifelong pancreatic enzyme replacement and insulin therapy [9, 180-183]. In near-total pancreatectomy, the tail, body, uncinate process and part of pancreatic head are resected, leaving a rim of pancreatic tissue surrounding the common bile duct and along the duodenum [9]. However, despite this radical pancreatectomy some children continue to have $\mathrm{HH}$ despite the removal of $95-98 \%$ of pancreatic tissue [181]. Diabetes can develop immediately after surgery or later on follow up [180]. These patients who undergo surgical resection should be monitored for glucose metabolism and diabetes [180-183].

\section{Follow up and outcome of congenital HH}

The management of severe $\mathrm{HH}$ patients is challenging and requires a multi-disciplinary approach. Integrating the

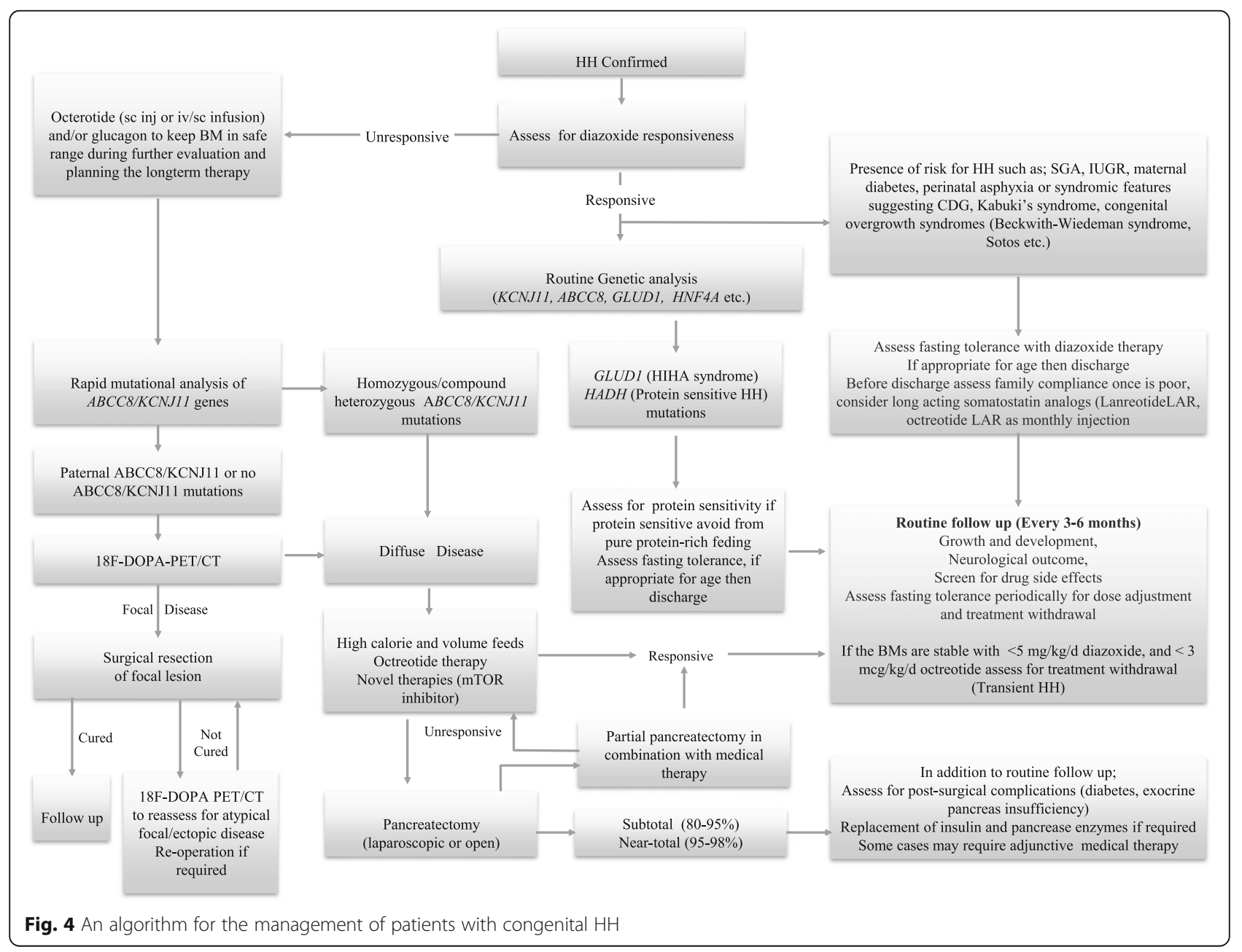


work of a team including clinicians, surgeons, specialized pathologists, geneticists, nurse specialists and dietitians would provide comprehensive management. Early identification and meticulous management of these patients is vital for preventing neurological sequelae. In the studies evaluating the long-term outcome of patients with $\mathrm{HH}$, a high frequency of neurodevelopmental retardation and various neurological disorders including epilepsy and microcephaly have been reported [91, 99, 183]. Besides, the incidence of abnormal neurodevelopment in transient and permanent cases have been found similar [99]. Severity of the disease (based on maximal diazoxide dose) and early presentation ( $<7$ days following birth) were significantly shown to be associated with abnormal neurodevelopment, while gender, underlying genetic etiology or the histopathological form of $\mathrm{HH}$ were not related to the neurological outcome [99]. Therefore, neurological development should be closely followed up. Early diagnosis, immediate treatment, definition of the histological subtype, and localization of the focal lesion prior to surgery and regular follow up may improve the outcome of patients.

On the other hand, to assess the efficacy of medical therapy, arranging a feeding plan appropriate to the individual fasting tolerance and adjusting the drug doses, repeated fasting tolerance test during follow up may be required [184]. Furthermore, since it is well known that the severity of $\mathrm{HH}$ becomes milder overtime, reassessment of fasting tolerance would ensure the cessation of any unnecessary medication [184, 185]. As some forms of congenital $\mathrm{HH}$ tend to improve over time, we recommend that patients should be assessed on a regular basis to see if their drugs can be stopped in the hospital setting. As a general guide; if the diazoxide dose is less than $5 \mathrm{mg} / \mathrm{kg} /$ day and octreotide is less than $3 \mathrm{mcg} / \mathrm{kg} / \mathrm{day}$ with no hypoglycaemic episdoes, then it might be possible to stop the medications and re-evaluate the patient. Figure 4 outlines management and follow-up of patients with congenital $\mathrm{HH}$. Finally, genetic counselling is recommended for the familial forms of $\mathrm{HH}$.

\section{Conclusions and future directions}

Congenital HH, the most severe cause of hypoglycaemia in the newborn and childhood period, is a complex heterogeneous condition in terms of variable clinical presentation, genetic background, histological subtype and reponse to the medical therapy. The molecular basis of CHI involves defects in key genes (ABCC8, KCNJ11, GLUD1, GCK, HADH, SLC16A1, HNF1A, HNF4A, UCP2, $H K 1, P G M 1$ and $P M M 2)$ which regulate insulin secretion. Rapid genetic analysis, imaging with ${ }^{18} \mathrm{~F}$-DOPA-PET/CT, new medical therapies and surgical techniques have largely contributed to the improvement in the management and outcome of the disease. Although our knowledge and experience about the disease and its management is improving, further research to identify underlying molecular genetics basis of the cases with unknown genetics is required. The discovery of these genes and the mechanisms involved would allow us to identify and develop novel therapeutic options and improve the outcome of this patient group.

\section{Abbreviations \\ (18F-DOPA) PET/CT: 18-F-fluoro-L-dihydroxyphenylalanine positron emission tomography; ABCC8: ATP Binding Cassette Subfamily C Member 8; \\ ADP: Adenosine diphosphate; CDG: Congenital disorders of glycosylation; FFA: Free fatty acids; GCK: Glucokinase; GDH: Glutamate dehydrogenase; GLP-1: Glucagon-like peptide-1; GLUD1: Glutamate dehydrogenase 1; GLUT2: Glucose transporter 2; HADH: Hydroxyacyl-CoA dehydrogenase; HH: Hyperinsulinaemic hypoglycaemia; HK1: Hexokinase 1; HNF: Hepatocyte nuclear factors; IUGR: Intrauterine growth restriction; $\mathrm{K}_{\text {ATP }}$ : ATP-sensitive potassium channels; KCNJ11: Potassium Voltage-Gated Channel Subfamily J Member 11; Kir6.2: Inwardly rectifying potassium; LAR: Long-acting release; MCT1: Monocarboxylate transporter; mTOR: mammalian target of rapamycin; PGM1: Phosphoglucomutase 1; PMM2: Phosphomannosmutase 2; PPAR: Peroxisome proliferators-activated receptor; SCHAD: Short chain L-3-hydroxyacyl-CoA dehydrogenase; SGA: Small for gestational age; SLC16A1: Solute Carrier Family 16 Member 1; SUR1: Sulphonlyurea receptor 1; UCP2: Uncoupling protein 2}

\section{Acknowledgements}

Not applicable.

Funding

Not applicable.

Availability of data and materials

Not applicable.

Authors' contributions

All authors participated in the conception and writing of the manuscript. Its final version was approved by all the authors.

Ethics approval and consent to participate Not applicable.

Consent for publication

Not applicable.

Competing interests

The authors declare that they have no competing interests.

\section{Publisher's Note}

Springer Nature remains neutral with regard to jurisdictional claims in published maps and institutional affiliations.

\section{Author details}

'Department of Paediatric Endocrinology, Hacettepe University, Faculty of Medicine, Ankara, Turkey. ${ }^{2}$ Great Ormond Street Institute of Child Health, Genetics and Genomic Medicine, University College London, 30 Guilford Street, London WC1N 1EH, UK. ${ }^{3}$ Department of Paediatric Medicine Sidra Medical \& Research Center, OPC, C6-337, PO Box 26999, Doha, Qatar.

Received: 7 June 2017 Accepted: 15 August 2017

Published online: 29 August 2017

\section{References}

1. Shah P, Rahman SA, Demirbilek H, Güemes M, Hussain K. Hyperinsulinaemic hypoglycaemia in children and adults. Lancet Diabetes Endocrinol 2016. doi: 10.1016/S2213-8587(16)30323-0.

2. Hussain K, Aynsley-Green A. Hyperinsulinism in infancy: understanding the pathophysiology. Int J Biochem Cell Biol. 2003;35:1312-7. 
3. Meissner T, Wendel U, Burgard P, Schaetzle S, Mayatepek E. Long-term follow-up of 114 patients with congenital hyperinsulinism. Eur J Endocrinol. 2003;149(1):43-51.

4. Arya VB, Flanagan SE, Kumaran A, Shield JP, Ellard S, Hussain K, Kapoor RR Clinical and molecular characterisation of hyperinsulinaemic hypoglycaemia in infants born small-for-gestational age. Arch Dis Child Fetal Neonatal Ed. 2013;98:F356-8

5. Kapoor RR, Flanagan SE, Arya VB, Shield JP, Ellard S, Hussain K. Clinical and molecular characterisation of 300 patients with congenital hyperinsulinism. Eur J Endocrinol. 2013;168:557-64.

6. Kelly A, Ng D, Ferry RJ Jr, Grimberg A, Koo-McCoy S, Thornton PS, Stanley CA. Acute insulin responses to leucine in children with the hyperinsulinism/ hyperammonemia syndrome. J Clin Endocrinol Metab. 2001;86:3724-8.

7. Li C, Najafi H, Daikhin Y, Nissim IB, Collins HW, Yudkoff M, Matschinsky FM, Stanley CA. Regulation of leucine-stimulated insulin secretion and glutamine metabolism in isolated rat islets. J Biol Chem. 2003;278:2853-8.

8. Meissner T, Otonkoski T, Feneberg R, Beinbrech B, Apostolidou S, Sipila I, Schaefer F, Mayatepek E. Exercise induced hypoglycaemic hyperinsulinism. Arch Dis Child. 2001;84:254-7.

9. Pierro A, Nah SA. Surgical management of congenital hyperinsulinism of infancy. Semin Pediatr Surg. 2011;20:50-3.

10. Kapoor RR, Flanagan SE, James C, Shield J, Ellard S, Hussain K. Hyperinsulinaemic hypoglycaemia. Arch Dis Child. 2009;94:450-7.

11. Hussain K, Aynsley-Green A. Management of hyperinsulinism in infancy and childhood. Ann Med. 2000;32:544-51.

12. Meintjes M, Endozo R, Dickson J, Erlandsson K, Hussain K, Townsend C, Menezes L, Bomanji J. 18F-DOPA PET and enhanced CT imaging for congenital hyperinsulinism: initial UK experience from a technologist's perspective. Nucl Med Commun. 2013;34:601-8.

13. Ismail D, Hussain K. Role of 18F-DOPA PET/CT imaging in congenital hyperinsulinism. Rev Endocr Metab Disord. 2010;11:165-9.

14. Kapoor RR, Heslegrave A, Hussain K. Congenital hyperinsulinism due to mutations in HNF4A and HADH. Rev Endocr Metab Disord. 2010;11:185-91.

15. Flanagan SE, Kapoor RR, Hussain K. Genetics of congenital hyperinsulinemic hypoglycemia. Semin Pediatr Surg. 2011;20:13-7.

16. Pinney SE, Ganapathy K, Bradfield J, Stokes D, Sasson A, Mackiewicz K, Boodhansingh K, Hughes N, Becker S, Givler S, et al. Dominant form of congenita hyperinsulinism maps to HK1 region on 10q. Horm Res Paediatr. 2013;80:18-27.

17. Tegtmeyer LC, Rust S, van Scherpenzeel M, Ng BG, Losfeld ME, Timal S, Raymond K, He P, Ichikawa M, Veltman J, et al. Multiple phenotypes in phosphoglucomutase 1 deficiency. N Engl J Med. 2014;370:533-42.

18. Ackermann AM LC, Freeze HH, Ficicioglu C, Kaestner KH, Stanley CA.: Hypoglycemia due to lower threshold of glucose-stimulated insulin secretion in phosphoglucomutase 1 deficiency. Platform presentation at: annual meeting of the pediatric academic societies, April 25-28, 2015; San Diego, CA platform presentation at: Annual Meeting of the Pediatric Academic Societies, April 25-28, 2015; San Diego, CA.

19. Cabezas OR, Flanagan SE, Stanescu H, Garcia-Martinez E, Caswell R, Lango-Allen H, Anton-Gamero M, Argente J, Bussell AM, Brandli A, et al: Polycystic Kidney Disease with Hyperinsulinemic Hypoglycemia Caused by a Promoter Mutation in Phosphomannomutase 2. J Am Soc Nephrol 2017;28(8):2529-39.

20. Cahill GF, Herrera MG, Morgan AP, Soeldner JS, Steinke J, Levy PL, Reichard GA, Kipnis DM. Hormone-fuel interrelationships during fasting. J Clin Invest. 1966:45:1751-69.

21. Newman JC, Verdin E. Ketone bodies as signaling metabolites. Trends Endocrinol Metab. 2014;25:42-52.

22. London ED, Margolin RA, Duara R, Holloway HW, Robertson-Tchabo EA, Cutler NR, Rapoport SI. Effects of fasting on ketone body concentrations in healthy men of different ages. J Gerontol. 1986;41:599-604.

23. Freemantle E, Vandal M, Tremblay Mercier J, Plourde M, Poirier J, Cunnane SC. Metabolic response to a ketogenic breakfast in the healthy elderly. J Nutr Health Aging. 2009;13:293-8.

24. Malaisse WJ, Sener A, Herchuelz A, Hutton JC. Insulin release: the fuel hypothesis. Metabolism. 1979;28:373-86.

25. Dunne MJ, Cosgrove KE, Shepherd RM, Aynsley-Green A, Lindley KJ. Hyperinsulinism in infancy: from basic science to clinical disease. Physiol Rev. 2004;84:239-75.

26. Johnson JH, Newgard CB, Milburn JL, Lodish HF, Thorens B. The high km glucose transporter of islets of Langerhans is functionally similar to the low affinity transporter of liver and has an identical primary sequence. J Biol Chem. 1990;265:6548-51.
27. Gould GW, Thomas HM, Jess TJ, Bell Gl. Expression of human glucose transporters in Xenopus oocytes: kinetic characterization and substrate specificities of the erythrocyte, liver, and brain isoforms. Biochemistry. 1991; 30:5139-45.

28. Matschinsky FM. Banting lecture 1995. A lesson in metabolic regulation inspired by the glucokinase glucose sensor paradigm. Diabetes. 1996;45: 223-41.

29. Cryer PE. Glucose counterregulation: prevention and correction of hypoglycemia in humans. Am J Phys. 1993;264:E149-55.

30. Cryer PE, Axelrod L, Grossman AB, Heller SR, Montori VM, Seaquist ER, Service FJ. Evaluation and management of adult hypoglycemic disorders: an Endocrine Society clinical practice guideline. J Clin Endocrinol Metab. 2009; 94:709-28.

31. Fafoula $\mathrm{O}$, Alkhayyat $\mathrm{H}$, Hussain K. Prolonged hyperinsulinaemic hypoglycaemia in newborns with intrauterine growth retardation. Arch Dis Child Fetal Neonatal Ed. 2006;91:F467.

32. Yap F, Hogler W, Vora A, Halliday R, Ambler G. Severe transient hyperinsulinaemic hypoglycaemia: two neonates without predisposing factors and a review of the literature. Eur J Pediatr. 2004;163:38-41.

33. Thomas PM, Cote GJ, Wohllk N, Haddad B, Mathew PM, Rabl W, Aguilar-Bryan L, Gagel RF, Bryan J. Mutations in the sulfonylurea receptor gene in familial persistent hyperinsulinemic hypoglycemia of infancy. Science. 1995;268:426-9.

34. Thomas $P, Y e Y$, Lightner $E$. Mutation of the pancreatic islet inward rectifier Kir6.2 also leads to familial persistent hyperinsulinemic hypoglycemia of infancy. Hum Mol Genet. 1996;5:1809-12.

35. Inagaki N, Gonoi T, Clement JP, Namba N, Inazawa J, Gonzalez G, Aguilar-Bryan L, Seino S, Bryan J. Reconstitution of IKATP: an inward rectifier subunit plus the sulfonylurea receptor. Science. 1995;270:1166-70.

36. Gribble FM, Reimann F. Sulphonylurea action revisited: the post-cloning era. Diabetologia. 2003;46:875-91.

37. Ashcroft FM, Gribble FM. New windows on the mechanism of action of K(ATP) channel openers. Trends Pharmacol Sci. 2000;21:439-45.

38. Rajan AS, Aguilar-Bryan L, Nelson DA, Nichols CG, Wechsler SW, Lechago J, Bryan J. Sulfonylurea receptors and ATP-sensitive K+ channels in clonal pancreatic alpha cells. Evidence for two high affinity sulfonylurea receptors. J Biol Chem. 1993;268:15221-8.

39. Shimono D, Fujimoto S, Mukai E, Takehiro M, Nabe K, Radu RG, Shimodahira M, Kominato R, Aramaki Y, Nishi Y, et al. ATP enhances exocytosis of insulin secretory granules in pancreatic islets under $\mathrm{Ca} 2+-$ depleted condition. Diabetes Res Clin Pract. 2005;69:216-23.

40. Gutgold A, Gross DJ, Glaser B, Szalat A. Diagnosis of ABCC8 congenital hyperinsulinism of infancy in a 20 year-old man evaluated for factitious hypoglycemia. J Clin Endocrinol Metab. 2017;102(2):345-49. doi:10.1210/jc. 2016-3254.

41. Lord K, Dzata E, Snider KE, Gallagher PR, De Leon DD. Clinical presentation and management of children with diffuse and focal hyperinsulinism: a review of 223 cases. J Clin Endocrinol Metab. 2013;98:E1786-9.

42. Snider KE, Becker S, Boyajian L, Shyng SL, MacMullen C, Hughes N, Ganapathy K, Bhatti T, Stanley CA, Ganguly A. Genotype and phenotype correlations in 417 children with congenital hyperinsulinism. J Clin Endocrinol Metab. 2013;98:E355-63.

43. Pinney SE, MacMullen C, Becker S, Lin YW, Hanna C, Thornton P, Ganguly A, Shyng SL, Stanley CA. Clinical characteristics and biochemical mechanisms of congenital hyperinsulinism associated with dominant KATP channel mutations. J Clin Invest. 2008;118:2877-86.

44. Arya VB, Guemes M, Nessa A, Alam S, Shah P, Gilbert C, Senniappan S, Flanagan SE, Ellard S, Hussain K. Clinical and histological heterogeneity of congenital hyperinsulinism due to paternally inherited heterozygous ABCC8/KCNJ11 mutations. Eur J Endocrinol. 2014;171:685-95.

45. Stanley CA. Perspective on the genetics and diagnosis of congenital Hyperinsulinism disorders. J Clin Endocrinol Metab. 2016;101:815-26.

46. Meissner T, Mayatepek E, Kinner M, Santer R. Urinary alpha-ketoglutarate is elevated in patients with hyperinsulinism-hyperammonemia syndrome. Clin Chim Acta. 2004;341:23-6.

47. Stanley CA, Lieu YK, Hsu BY, Burlina AB, Greenberg CR, Hopwood NJ, Perlman K, Rich BH, Zammarchi E, Poncz M. Hyperinsulinism and hyperammonemia in infants with regulatory mutations of the glutamate dehydrogenase gene. N Engl J Med. 1998;338:1352-7.

48. Stanley CA, Fang J, Kutyna K, Hsu BY, Ming JE, Glaser B, Poncz M. Molecular basis and characterization of the hyperinsulinism/hyperammonemia 
syndrome: predominance of mutations in exons 11 and 12 of the glutamate dehydrogenase gene. HI/HA Contributing Investigators. Diabetes. 2000;49:667-73.

49. Weinzimer SA, Stanley CA, Berry GT, Yudkoff M, Tuchman M, Thornton PS. A syndrome of congenital hyperinsulinism and hyperammonemia. J Pediatr. 1997;130:661-4.

50. Sarajlija A, Milenkovic T, Djordjevic M, Mitrovic K, Todorovic S, Kecman B, Hussain K. Early presentation of Hyperinsulinism/Hyperammonemia syndrome in three Serbian patients. J Clin Res Pediatr Endocrinol. 2016;8:228-31.

51. Agren A, Borg K, Brolin SE, Carlman J, Lundqvist G. Hydroxyacyl CoA dehydrogenase, an enzyme important in fat metabolism in different cell types in the islets of Langerhans. Diabete Metab. 1977;3:169-72.

52. Li C, Chen P, Palladino A, Narayan S, Russell LK, Sayed S, Xiong G, Chen J, Stokes D, Butt YM, et al. Mechanism of hyperinsulinism in short-chain 3-hydroxyacyl-CoA dehydrogenase deficiency involves activation of glutamate dehydrogenase. J Biol Chem. 2010;285:31806-18.

53. Heslegrave AJ, Kapoor RR, Eaton S, Chadefaux B, Akcay T, Simsek E, Flanagan SE, Ellard S, Hussain K. Leucine-sensitive hyperinsulinaemic hypoglycaemia in patients with loss of function mutations in 3-HydroxyacylCoA Dehydrogenase. Orphanet J Rare Dis. 2012;7:25.

54. Molven A, Matre GE, Duran M, Wanders RJ, Rishaug U, Njolstad PR, Jellum E, Sovik O. Familial hyperinsulinemic hypoglycemia caused by a defect in the SCHAD enzyme of mitochondrial fatty acid oxidation. Diabetes. 2004;53:221-7.

55. Heslegrave AJ, Hussain K. Novel insights into fatty acid oxidation, amino acid metabolism, and insulin secretion from studying patients with loss of function mutations in 3-hydroxyacyl-CoA dehydrogenase. J Clin Endocrinol Metab. 2013;98:496-501.

56. Babiker O, Flanagan SE, Ellard S, Al Girim H, Hussain K, Senniappan S. Protein-induced hyperinsulinaemic hypoglycaemia due to a homozygous HADH mutation in three siblings of a Saudi family. J Pediatr Endocrinol Metab. 2015;28:1073-7

57. Clayton PT, Eaton S, Aynsley-Green A, Edginton M, Hussain K, Krywawych S, Datta V, Malingre HE, Berger R, van den Berg IE. Hyperinsulinism in short-chain L-3-hydroxyacyl-CoA dehydrogenase deficiency reveals the importance of beta-oxidation in insulin secretion. J Clin Invest. 2001;108:457-65.

58. Iynedjian PB, Pilot PR, Nouspikel T, Milburn JL, Quaade C, Hughes S, Ucla C, Newgard CB. Differential expression and regulation of the glucokinase gene in liver and islets of Langerhans. Proc Natl Acad Sci U S A. 1989;86:7838-42.

59. Matschinsky FM. Regulation of pancreatic beta-cell glucokinase: from basics to therapeutics. Diabetes. 2002;51(Suppl 3):S394-404.

60. Kukuvitis A, Deal C, Arbour L, Polychronakos C. An autosomal dominant form of familial persistent hyperinsulinemic hypoglycemia of infancy, not linked to the sulfonylurea receptor locus. J Clin Endocrinol Metab. 1997;82:1192-4.

61. Martinez R, Gutierrez-Nogues A, Fernandez-Ramos C, Velayos T, Vela A Navas MA, Castano L. Heterogeneity in phenotype of hyperinsulinism caused by activating glucokinase mutations: a novel mutation and its functional characterization. Clin Endocrinol. 2017;

62. Barbetti F, Cobo-Vuilleumier N, Dionisi-Vici C, Toni S, Ciampalini P, Massa O, Rodriguez-Bada P, Colombo C, Lenzi L, Garcia-Gimeno MA, et al. Opposite clinical phenotypes of glucokinase disease: description of a novel activating mutation and contiguous inactivating mutations in human glucokinase (GCK) gene. Mol Endocrinol. 2009;23:1983-9.

63. Morishita K, Kyo C, Yonemoto T, Kosugi R, Ogawa T, Inoue T. Asymptomatic congenital Hyperinsulinism due to a Glucokinase-activating mutation, treated as adrenal insufficiency for twelve years. Case Rep Endocrinol. 2017; 2017:4709262

64. Cuesta-Munoz AL, Huopio H, Otonkoski T, Gomez-Zumaquero JM, Nanto-Salonen K, Rahier J, Lopez-Enriquez S, Garcia-Gimeno MA, Sanz P, Soriguer FC, Laakso M. Severe persistent hyperinsulinemic hypoglycemia due to a de novo glucokinase mutation. Diabetes. 2004;53:2164-8.

65. Ajala ON, Huffman DM, Ghobrial II. Glucokinase mutation-a rare cause of recurrent hypoglycemia in adults: a case report and literature review. J Community Hosp Intern Med Perspect. 2016;6:32983.

66. Sekine N, Cirulli V, Regazzi R, Brown L, Gine E, Tamarit-Rodriguez J, Girotti M, Marie S, MacDonald MJ, Wollheim CB, et al. Low lactate dehydrogenase and high mitochondrial glycerol phosphate dehydrogenase in pancreatic betacells. Potential role in nutrient sensing. J Biol Chem. 1994;269:4895-902.

67. Pullen TJ, Sylow L, Sun G, Halestrap AP, Richter EA, Rutter GA. Overexpression of monocarboxylate transporter-1 (SLC16A1) in mouse pancreatic beta-cells leads to relative hyperinsulinism during exercise. Diabetes. 2012;61:1719-25.
68. Otonkoski T, Kaminen N, Ustinov J, Lapatto R, Meissner T, Mayatepek E, Kere J, Sipila I. Physical exercise-induced hyperinsulinemic hypoglycemia is an autosomal-dominant trait characterized by abnormal pyruvate-induced insulin release. Diabetes. 2003:52:199-204.

69. Miura A, Yamagata K, Kakei M, Hatakeyama H, Takahashi N, Fukui K, Nammo $\mathrm{T}$, Yoneda $\mathrm{K}$, Inoue $\mathrm{Y}$, Sladek FM, et al. Hepatocyte nuclear factor-4alpha is essential for glucose-stimulated insulin secretion by pancreatic beta-cells. J Biol Chem. 2006;281:5246-57.

70. Taraviras S, Monaghan AP, Schutz G, Kelsey G. Characterization of the mouse HNF-4 gene and its expression during mouse embryogenesis. Mech Dev. 1994:48:67-79.

71. Pearson ER, Boj SF, Steele AM, Barrett T, Stals K, Shield JP, Ellard S, Ferrer J, Hattersley AT. Macrosomia and hyperinsulinaemic hypoglycaemia in patients with heterozygous mutations in the HNF4A gene. PLoS Med. 2007; 4:e118.

72. Yamagata K, Furuta H, Oda N, Kaisaki PJ, Menzel S, Cox NJ, Fajans SS, Signorini S, Stoffel M, Bell Gl. Mutations in the hepatocyte nuclear factor4alpha gene in maturity-onset diabetes of the young (MODY1). Nature. 1996:384:458-60.

73. Yamagata K, Oda N, Kaisaki PJ, Menzel S, Furuta H, Vaxillaire M, Southam L, Cox RD, Lathrop GM, Boriraj W, et al. Mutations in the hepatocyte nuclear factor-1alpha gene in maturity-onset diabetes of the young (MODY3). Nature. 1996;384:455-8.

74. Pontoglio M, Sreenan S, Roe M, Pugh W, Ostrega D, Doyen A, Pick AJ, Baldwin A, Velho G, Froguel $P$, et al. Defective insulin secretion in hepatocyte nuclear factor 1alpha-deficient mice. J Clin Invest. 1998;101: 2215-22.

75. Gupta RK, Vatamaniuk MZ, Lee CS, Flaschen RC, Fulmer JT, Matschinsky FM, Duncan SA, Kaestner KH. The MODY1 gene HNF-4alpha regulates selected genes involved in insulin secretion. J Clin Invest. 2005;115:1006-15.

76. Sugden MC, Holness MJ. Potential role of peroxisome proliferator-activated receptor-alpha in the modulation of glucose-stimulated insulin secretion. Diabetes. 2004;53(Suppl 1):S71-81.

77. Gremlich S, Nolan C, Roduit R, Burcelin R, Peyot ML, Delghingaro-Augusto V, Desvergne B, Michalik L, Prentki M, Wahli W. Pancreatic islet adaptation to fasting is dependent on peroxisome proliferator-activated receptor alpha transcriptional up-regulation of fatty acid oxidation. Endocrinology. 2005; 146:375-82.

78. Fajans SS, Bell Gl. Macrosomia and neonatal hypoglycaemia in RW pedigree subjects with a mutation (Q268X) in the gene encoding hepatocyte nuclear factor 4alpha (HNF4A). Diabetologia. 2007;50:2600-1.

79. Kapoor RR, Locke J, Colclough K, Wales J, Conn JJ, Hattersley AT, Ellard S, Hussain K. Persistent hyperinsulinemic hypoglycemia and maturity-onset diabetes of the young due to heterozygous HNF4A mutations. Diabetes. 2008:57:1659-63.

80. Flanagan SE, Kapoor RR, Mali G, Cody D, Murphy N, Schwahn B, Siahanidou T, Banerjee I, Akcay T, Rubio-Cabezas O, et al. Diazoxide-responsive hyperinsulinemic hypoglycemia caused by HNF4A gene mutations. Eur J Endocrinol. 2010;162:987-92.

81. Stanik J, Skopkova M, Brennerova K, Danis D, Rosolankova M, Salingova A, Bzduch V, Klimes I, Gasperikova D. Congenital hyperinsulinism and glycogenosis-like phenotype due to a novel HNF4A mutation. Diabetes Res Clin Pract. 2017:126:144-50.

82. Stanescu DE, Hughes N, Kaplan B, Stanley CA, De León DD. Novel presentations of congenital Hyperinsulinism due to mutations in the MODY genes: HNF1A and HNF4A. J Clin Endocrinol Metab. 2012;97:E2026-30.

83. Rozenkova K, Malikova J, Nessa A, Dusatkova L, Bjorkhaug L, Obermannova B, Dusatkova P, Kytnarova J, Aukrust I, Najmi LA, et al. High incidence of heterozygous ABCC8 and HNF1A mutations in Czech patients with congenital Hyperinsulinism. J Clin Endocrinol Metab. 2015; 100:E1540-9.

84. Vozza A, Parisi G, De Leonardis F, Lasorsa FM, Castegna A, Amorese D, Marmo R, Calcagnile VM, Palmieri L, Ricquier D, et al. UCP2 transports C4 metabolites out of mitochondria, regulating glucose and glutamine oxidation. Proc Natl Acad Sci U S A. 2014;111:960-5.

85. Gonzalez-Barroso MM, Giurgea I, Bouillaud F, Anedda A, Bellanne-Chantelot C, Hubert L, de Keyzer Y, de Lonlay P, Ricquier D. Mutations in UCP2 in congenital hyperinsulinism reveal a role for regulation of insulin secretion. PLoS One. 2008;3:e3850.

86. Mc QI. Idiopathic spontaneously occurring hypoglycemia in infants; clinical significance of problem and treatment. AMA Am J Dis Child. 1954;87:399-428. 
87. Ferrara $C T$, Boodhansingh KE, Paradies E, Giuseppe F, Steinkrauss $L$, Topor LS, Quintos JB, Ganguly A, De Leon DD, Palmieri F, Stanley CA. Novel Hypoglycemia Phenotype in Congenital Hyperinsulinism Due to Dominant Mutations of Uncoupling Protein 2. J Clin Endocrinol Metab. 2017;102(3): 942-49. doi:10.1210/jc.2016-3164.

88. Davis LM, Pauly JR, Readnower RD, Rho JM, Sullivan PG. Fasting is neuroprotective following traumatic brain injury. J Neurosci Res. 2008;86: 1812-22.

89. Straussman S, Levitsky LL. Neonatal hypoglycemia. Curr Opin Endocrinol Diabetes Obes. 2010;17:20-4.

90. Su J, Wang L. Research advances in neonatal hypoglycemic brain injury. Transl Pediatr. 2012;1:108-15.

91. Meissner T, Wendel U, Burgard P, Schaetzle S, Mayatepek E. Long-term follow-up of 114 patients with congenital hyperinsulinism. Eur J Endocrinol. 2003; 149:43-51.

92. Huopio H, Shyng SL, Otonkoski T, Nichols CG. K(ATP) channels and insulin secretion disorders. Am J Physiol Endocrinol Metab. 2002;283:E207-16.

93. Schwitzgebel VM, Gitelman SE. Neonatal hyperinsulinism. Clin Perinatol. 1998:25:1015-38. viii

94. Hoe FM, Thornton PS, Wanner LA, Steinkrauss L, Simmons RA, Stanley CA. Clinical features and insulin regulation in infants with a syndrome of prolonged neonatal hyperinsulinism. J Pediatr. 2006;148:207-12.

95. Palladino AA, Bennett MJ, Stanley CA. Hyperinsulinism in infancy and childhood: when an insulin level is not always enough. Clin Chem. 2008;54: 256-63.

96. Hsu BY, Kelly A, Thornton PS, Greenberg CR, Dilling LA, Stanley CA. Proteinsensitive and fasting hypoglycemia in children with the hyperinsulinism/ hyperammonemia syndrome. J Pediatr. 2001;138:383-9.

97. Finegold DN, Stanley CA, Baker L. Glycemic response to glucagon during fasting hypoglycemia: an aid in the diagnosis of hyperinsulinism. J Pediatr. 1980;96:257-9

98. Levitt Katz LE, Satin-Smith MS, Collett-Solberg P, Thornton PS, Baker L, Stanley CA, Cohen P. Insulin-like growth factor binding protein-1 levels in the diagnosis of hypoglycemia caused by hyperinsulinism. J Pediatr. 1997; 131:193-9.

99. Menni F, de Lonlay P, Sevin C, Touati G, Peigne C, Barbier V, Nihoul-Fekete C, Saudubray JM, Robert JJ. Neurologic outcomes of 90 neonates and infants with persistent hyperinsulinemic hypoglycemia. Pediatrics. 2001;107:476-9.

100. Kapoor RR, James C, Hussain K. Advances in the diagnosis and management of hyperinsulinemic hypoglycemia. Nat Clin Pract Endocrinol Metab. 2009;5: 101-12

101. Senniappan S, Shanti B, James C, Hussain K. Hyperinsulinaemic hypoglycaemia: genetic mechanisms, diagnosis and management. J Inherit Metab Dis. 2012;35:589-601.

102. Hussain K. Diagnosis and management of hyperinsulinaemic hypoglycaemia of infancy. Horm Res. 2008;69:2-13.

103. Shah $P$, Demirbilek H, Hussain K. Persistent hyperinsulinaemic hypoglycaemia in infancy. Semin Pediatr Surg. 2014;23:76-82

104. Goldfine AB, Mun EC, Devine E, Bernier R, Baz-Hecht M, Jones DB, Schneider $\mathrm{BE}$, Holst JJ, Patti ME. Patients with neuroglycopenia after gastric bypass surgery have exaggerated incretin and insulin secretory responses to a mixed meal. J Clin Endocrinol Metab. 2007;92:4678-85.

105. Neylon OM, Moran MM, Pellicano A, Nightingale M, O'Connell MA Successful subcutaneous glucagon use for persistent hypoglycaemia in congenital hyperinsulinism. J Pediatr Endocrinol Metab. 2013;26:1157-61.

106. Mohnike K, Blankenstein O, Pfuetzner A, Potzsch S, Schober E, Steiner S, Hardy OT, Grimberg A, van Waarde WM. Long-term non-surgical therapy of severe persistent congenital hyperinsulinism with glucagon. Horm Res. 2008:70:59-64.

107. Banerjee I, Forsythe L, Skae M, Avatapalle HB, Rigby L, Bowden LE, Craigie R, Padidela R, Ehtisham S, Patel L, et al. Feeding problems are persistent in children with severe congenital Hyperinsulinism. Front Endocrinol (Lausanne). 2016;7:8.

108. Al-Shanafey S, Alkhudhur H. Food aversion among patients with persistent hyperinsulinemic hypoglycemia of infancy. J Pediatr Surg. 2012;47:895-7.

109. Aynsley-Green A, Hussain K, Hall J, Saudubray JM, Nihoul-Fekete C, De Lonlay-Debeney P, Brunelle F, Otonkoski T, Thornton P, Lindley KJ. Practical management of hyperinsulinism in infancy. Arch Dis Child Fetal Neonatal Ed. 2000;82:F98-f107.

110. Welters A, Lerch C, Kummer S, Marquard J, Salgin B, Mayatepek E, Meissner T. Long-term medical treatment in congenital hyperinsulinism: a descriptive analysis in a large cohort of patients from different clinical centers. Orphanet J Rare Dis. 2015;10:150.

111. Lord K, De Leon DD. Monogenic hyperinsulinemic hypoglycemia: current insights into the pathogenesis and management. Int J Pediatr Endocrinol. 2013;2013:3.

112. Yildizdas D, Erdem S, Kucukosmanoglu O, Yilmaz M, Yuksel B. Pulmonary hypertension, heart failure and neutropenia due to diazoxide therapy. Adv Ther. 2008;25:515-9.

113. Arya VB, Mohammed Z, Blankenstein O, De Lonlay P, Hussain K Hyperinsulinaemic hypoglycaemia. Horm Metab Res. 2014;46:157-70.

114. Katz MD, Erstad BL. Octreotide, a new somatostatin analogue. Clin Pharm. 1989:8:255-73.

115. Doyle ME, Egan JM. Pharmacological agents that directly modulate insulin secretion. Pharmacol Rev. 2003;55:105-31.

116. Yorifuji T, Kawakita R, Hosokawa Y, Fujimaru R, Matsubara K, Aizu K, Suzuki S, Nagasaka $H$, Nishibori $H$, Masue M. Efficacy and safety of long-term, continuous subcutaneous octreotide infusion for patients with different subtypes of KATP-channel hyperinsulinism. Clin Endocrinol. 2013;78:891-7.

117. Wahid ST, Marbach P, Stolz B, Miller M, James RA, Ball SG. Partial tachyphylaxis to somatostatin (SST) analogues in a patient with acromegaly: the role of SST receptor desensitisation and circulating antibodies to SST analogues. Eur J Endocrinol. 2002;146:295-302.

118. Escorsell A, Bandi JC, Andreu V, Moitinho E, Garcia-Pagan JC, Bosch J, Rodes J. Desensitization to the effects of intravenous octreotide in cirrhotic patients with portal hypertension. Gastroenterology. 2001;120:161-9.

119. Hawkes CP, Adzick NS, Palladino AA, De Leon DD: Late Presentation of Fulminant Necrotizing Enterocolitis in a Child with Hyperinsulinism on Octreotide Therapy. Horm Res Paediatr. 2016;86(2):131-36.

120. Levy-Khademi F, Irina S, Avnon-Ziv C, Levmore-Tamir M, Leder O. Octreotide-associated cholestasis and hepatitis in an infant with congenital hyperinsulinism. J Pediatr Endocrinol Metab. 2015;28:449-51.

121. Demirbilek H, Shah P, Arya VB, Hinchey L, Flanagan SE, Ellard S, Hussain K. Long-term follow-up of children with congenital hyperinsulinism on octreotide therapy. J Clin Endocrinol Metab. 2014;99:3660-7.

122. Celik N, Cinaz P, Emeksiz HC, Hussain K, Camurdan O, Bideci A, Doger $E_{\text {, }}$ Yuce O, Turkyilmaz Z, Oguz AD. Octreotide-induced long QT syndrome in a child with congenital hyperinsulinemia and a novel missense mutation (p.Met115Val) in the ABCC8 gene. Horm Res Paediatr. 2013;80:299-303.

123. Koren I, Riskin A, Barthlen W, Gillis D. Hepatitis in an infant treated with octreotide for congenital hyperinsulinism. J Pediatr Endocrinol Metab. 2013; 26:183-5.

124. Harris AG. Somatostatin and somatostatin analogues: pharmacokinetics and pharmacodynamic effects. Gut. 1994;35:S1-4.

125. McMahon AW, Wharton GT, Thornton P, De Leon DD. Octreotide use and safety in infants with hyperinsulinism. Pharmacoepidemiol Drug Saf. 2017; 26:26-31.

126. Hawkes CP, Adzick NS, Palladino AA, De Leon DD. Late presentation of Fulminant necrotizing Enterocolitis in a child with Hyperinsulinism on Octreotide therapy. Horm Res Paediatr. 2016;86:131-6.

127. Petersen H, Bizec JC, Schuetz H, Delporte ML. Pharmacokinetic and technical comparison of Sandostatin(R) LAR(R) and other formulations of long-acting octreotide. BMC Res Notes. 2011;4:344.

128. Shah P, Rahman SA, McElroy S, Gilbert C, Morgan K, Hinchey L, Senniappan S, Levy H, Amin R, Hussain K. Use of long-acting Somatostatin analogue (Lanreotide) in an adolescent with Diazoxide-responsive congenital Hyperinsulinism and its psychological impact. Horm Res Paediatr. 2015;84:355-60.

129. Kuhnen P, Marquard J, Ernert A, Meissner T, Raile K, Wannenmacher G, Blankenstein O. Long-term lanreotide treatment in six patients with congenital hyperinsulinism. Horm Res Paediatr. 2012;78:106-12.

130. Modan-Moses D, Koren I, Mazor-Aronovitch K, Pinhas-Hamiel O, Landau H. Treatment of congenital hyperinsulinism with lanreotide acetate (Somatuline autogel). J Clin Endocrinol Metab. 2011;96:2312-7.

131. Al-Zubeidi H, Gottschalk ME, Newfield RS. Successful use of long acting octreotide in two cases with Beckwith-Wiedemann syndrome and severe hypoglycemia. Int J Pediatr Endocrinol. 2014;2014:18.

132. Le Quan Sang KH, Arnoux JB, Mamoune A, Saint-Martin C, Bellanne-Chantelot C, Valayannopoulos V, Brassier A, Kayirangwa H, Barbier V, Broissand C, et al. Successful treatment of congenital hyperinsulinism with long-acting release octreotide. Eur J Endocrinol. 2012;166:333-9.

133. Mergler S, Singh V, Grotzinger C, Kaczmarek P, Wiedenmann B, Strowski MZ. Characterization of voltage operated R-type Ca2+ channels in modulating 
somatostatin receptor subtype 2- and 3-dependent inhibition of insulin secretion from INS-1 cells. Cell Signal. 2008:20:2286-95.

134. Durmaz E, Flanagan SE, Parlak M, Ellard S, Akcurin S, Bircan I. A combination of nifedipine and octreotide treatment in an hyperinsulinemic hypoglycemic infant. J Clin Res Pediatr Endocrinol. 2014;6:119-21.

135. Güemes M, Shah P, Silvera S, Morgan K, Gilbert C, Hinchey L, Hussain K. Assessment of Nifedipine therapy in Hyperinsulinemic hypoglycemia due to mutations in the ABCC8 gene. The Journal of Clinical Endocrinology \& Metabolism. 2017;102:822-30.

136. Eichmann D, Hufnagel M, Quick P, Santer R. Treatment of hyperinsulinaemic hypoglycaemia with nifedipine. Eur J Pediatr. 1999;158:204-6.

137. Bas F, Darendeliler F, Demirkol D, Bundak R, Saka N, Gunoz H. Successful therapy with calcium channel blocker (nifedipine) in persistent neonatal hyperinsulinemic hypoglycemia of infancy. J Pediatr Endocrinol Metab. 1999;12:873-8.

138. Shanbag P, Pathak A, Vaidya M, Shahid SK. Persistent hyperinsulinemic hypoglycemia of infancy-successful therapy with nifedipine. Indian J Pediatr. 2002;69:271-2.

139. Khawash P, Hussain K, Flanagan SE, Chatterjee S, Basak D. Nifedipine in congenital Hyperinsulinism - a case report. J Clin Res Pediatr Endocrinol. 2015;7:151-4.

140. Meyuhas $O$. Synthesis of the translational apparatus is regulated at the translational level. Eur J Biochem. 2000;267:6321-30.

141. Alexandrescu S, Tatevian N, Olutoye O, Brown RE. Persistent hyperinsulinemic hypoglycemia of infancy: constitutive activation of the mTOR pathway with associated exocrine-islet transdifferentiation and therapeutic implications. Int J Clin Exp Pathol. 2010;3:691-705.

142. Wullschleger $\mathrm{S}$, Loewith $\mathrm{R}$, Hall MN. TOR signaling in growth and metabolism. Cell. 2006;124:471-84.

143. Leibiger IB, Leibiger B, Moede T, Berggren PO. Exocytosis of insulin promotes insulin gene transcription via the insulin receptor/PI-3 kinase/p70 s6 kinase and CaM kinase pathways. Mol Cell. 1998;1:933-8.

144. Senniappan S, Alexandrescu S, Tatevian N, Shah P, Arya V, Flanagan S, Ellard S, Rampling D, Ashworth M, Brown RE, Hussain K. Sirolimus therapy in infants with severe hyperinsulinemic hypoglycemia. N Engl J Med. 2014;370: 1131-7.

145. Abraham MB, Shetty VB, Price G, Smith N, Bock M, Siafarikas A, Resnick S, Whan E, Ellard S, Flanagan SE, et al. Efficacy and safety of sirolimus in a neonate with persistent hypoglycaemia following near-total pancreatectomy for hyperinsulinaemic hypoglycaemia. J Pediatr Endocrinol Metab. 2015;28:1391-8.

146. Minute M, Patti G, Tornese G, Faleschini E, Zuiani C, Ventura A. Sirolimus therapy in congenital Hyperinsulinism: a successful experience beyond infancy. Pediatrics. 2015;136:e1373-6.

147. Unal S, Gonulal D, Ucakturk A, Siyah Bilgin B, Flanagan SE, Gurbuz F, Tayfun M, Elmaogullari S, Arasli A, Demirel F, et al. A novel homozygous mutation in the KCNJ11 gene of a neonate with congenital Hyperinsulinism and successful management with Sirolimus. J Clin Res Pediatr Endocrinol. 2016;8:478-81.

148. Meder U, Bokodi G, Balogh L, Korner A, Szabo M, Pruhova S, Szabo AJ. Severe Hyperinsulinemic hypoglycemia in a neonate: response to Sirolimus therapy. Pediatrics. 2015;136:e1369-72.

149. Shah P, Arya VB, Flanagan SE, Morgan K, Ellard S, Senniappan S, Hussain K. Sirolimus therapy in a patient with severe hyperinsulinaemic hypoglycaemia due to a compound heterozygous ABCC8 gene mutation. J Pediatr Endocrinol Metab. 2015;28:695-9.

150. Sankhala K, Mita A, Kelly K, Mahalingam D, Giles F, Mita M. The emerging safety profile of mTOR inhibitors, a novel class of anticancer agents. Target Oncol. 2009;4:135-42.

151. Szymanowski M, Estebanez MS, Padidela R, Han B, Mosinska K, Stevens A, Damaj L, Pihan-Le Bars F, Lascouts E, Reynaud R, et al. mTOR inhibitors for the treatment of severe congenital Hyperinsulinism: perspectives on limited therapeutic success. J Clin Endocrinol Metab. 2016;101:4719-29.

152. De Leon DD, Crutchlow MF, Ham JY, Stoffers DA. Role of glucagon-like peptide-1 in the pathogenesis and treatment of diabetes mellitus. Int J Biochem Cell Biol. 2006;38:845-59.

153. Thorens B. Expression cloning of the pancreatic beta cell receptor for the gluco-incretin hormone glucagon-like peptide 1. Proc Natl Acad Sci U S A 1992;89:8641-5

154. Gromada J, Holst JJ, Rorsman P. Cellular regulation of islet hormone secretion by the incretin hormone glucagon-like peptide 1. Pflugers Arch. 1998;435:583-94.
155. Renstrom E, Eliasson L, Rorsman P. Protein kinase A-dependent and -independent stimulation of exocytosis by CAMP in mouse pancreatic B-cells. J Physiol. 1997;502(Pt 1):105-18.

156. Edwards CM, Todd JF, Mahmoudi M, Wang Z, Wang RM, Ghatei MA, Bloom SR. Glucagon-like peptide 1 has a physiological role in the control of postprandial glucose in humans: studies with the antagonist exendin 9-39. Diabetes. 1999;48:86-93.

157. Schirra J, Sturm K, Leicht P, Arnold R, Goke B, Katschinski M. Exendin (9-39)amide is an antagonist of glucagon-like peptide-1(7-36)amide in humans. J Clin Invest. 1998;101:1421-30.

158. De Leon DD, Li C, Delson MI, Matschinsky FM, Stanley CA, Stoffers DA. Exendin-(9-39) corrects fasting hypoglycemia in SUR-1-/- mice by lowering CAMP in pancreatic beta-cells and inhibiting insulin secretion. J Biol Chem. 2008;283:25786-93.

159. Calabria AC, Li C, Gallagher PR, Stanley CA, De Leon DD. GLP-1 receptor antagonist exendin-(9-39) elevates fasting blood glucose levels in congenital hyperinsulinism owing to inactivating mutations in the ATP-sensitive K+ channel. Diabetes. 2012;61:2585-91.

160. Yan FF, Casey J, Shyng SL. Sulfonylureas correct trafficking defects of disease-causing ATP-sensitive potassium channels by binding to the channel complex. J Biol Chem. 2006;281:33403-13.

161. Chen PC, Olson EM, Zhou Q, Kryukova Y, Sampson HM, Thomas DY, Shyng SL. Carbamazepine as a novel small molecule corrector of traffickingimpaired ATP-sensitive potassium channels identified in congenital hyperinsulinism. J Biol Chem. 2013;288:20942-54.

162. Martin GM, Rex EA, Devaraneni P, Denton JS, Boodhansingh KE, DeLeon DD, Stanley CA, Shyng SL. Pharmacological correction of trafficking defects in ATP-sensitive potassium channels caused by sulfonylurea receptor 1 mutations. J Biol Chem. 2016;291:21971-83.

163. Nehlig A. Pereira de Vasconcelos a: glucose and ketone body utilization by the brain of neonatal rats. Prog Neurobiol. 1993;40:163-221.

164. Owen OE, Morgan AP, Kemp HG, Sullivan JM, Herrera MG, Cahill GF Jr. Brain metabolism during fasting. J Clin Invest. 1967:46:1589-95.

165. Yudkoff M, Daikhin Y, Nissim I, Lazarow A, Nissim I. Ketogenic diet, amino acid metabolism, and seizure control. J Neurosci Res. 2001;66:931-40.

166. Yamada KA, Rensing N, Thio LL. Ketogenic diet reduces hypoglycemiainduced neuronal death in young rats. Neurosci Lett. 2005;385:210-4.

167. Maiorana A, Manganozzi L, Barbetti F, Bernabei S, Gallo G, Cusmai R, Caviglia S, Dionisi-Vici C. Ketogenic diet in a patient with congenital hyperinsulinism: a novel approach to prevent brain damage. Orphanet J Rare Dis. 2015;10:120.

168. Sempoux C, Guiot Y, Jaubert F, Rahier J. Focal and diffuse forms of congenital hyperinsulinism: the keys for differential diagnosis. Endocr Pathol. 2004;15:241-6.

169. Verkarre V, Fournet JC, de Lonlay P, Gross-Morand MS, Devillers M, Rahier J, Brunelle F, Robert JJ, Nihoul-Fekete C, Saudubray JM, Junien C. Paternal mutation of the sulfonylurea receptor (SUR1) gene and maternal loss of 11 p15 imprinted genes lead to persistent hyperinsulinism in focal adenomatous hyperplasia. J Clin Invest. 1998;102:1286-91.

170. Sempoux C, Capito C, Bellanne-Chantelot C, Verkarre V, de Lonlay P, Aigrain $Y$, Fekete C, Guiot Y, Rahier J. Morphological mosaicism of the pancreatic islets: a novel anatomopathological form of persistent hyperinsulinemic hypoglycemia of infancy. J Clin Endocrinol Metab. 2011;96:3785-93.

171. Hardy OT, Hernandez-Pampaloni M, Saffer JR, Scheuermann JS, Ernst LM, Freifelder R, Zhuang H, MacMullen C, Becker S, Adzick NS, et al. Accuracy of [18F]fluorodopa positron emission tomography for diagnosing and localizing focal congenital hyperinsulinism. J Clin Endocrinol Metab. 2007;92:4706-11.

172. Rahier J, Guiot Y, Sempoux C. Morphologic analysis of focal and diffuse forms of congenital hyperinsulinism. Semin Pediatr Surg. 2011;20:3-12.

173. Han B, Newbould M, Batra G, Cheesman E, Craigie RJ, Mohamed Z, Rigby L, Padidela R, Skae M, Mironov A, et al. Enhanced islet cell Nucleomegaly defines diffuse congenital Hyperinsulinism in infancy but not other forms of the disease. Am J Clin Pathol. 2016;145:757-68.

174. James C, Kapoor RR, Ismail D, Hussain K. The genetic basis of congenital hyperinsulinism. J Med Genet. 2009;46:289-99.

175. Mohnike K, Blankenstein O, Minn H, Mohnike W, Fuchtner F. Otonkoski T: [18F]-DOPA positron emission tomography for preoperative localization in congenital hyperinsulinism. Horm Res. 2008;70:65-72.

176. Otonkoski T, Nanto-Salonen K, Seppanen M, Veijola R, Huopio H, Hussain K, Tapanainen P, Eskola O, Parkkola R, Ekstrom K, et al. Noninvasive diagnosis of focal hyperinsulinism of infancy with [18F]-DOPA positron emission tomography. Diabetes. 2006;55:13-8. 
177. Rahier J, Sempoux C, Fournet JC, Poggi F, Brunelle F, Nihoul-Fekete C, Saudubray JM, Jaubert F. Partial or near-total pancreatectomy for persistent neonatal hyperinsulinaemic hypoglycaemia: the pathologist's role. Histopathology. 1998:32:15-9.

178. Rahman SA, Nessa A, Hussain K. Molecular mechanisms of congenital hyperinsulinism. J Mol Endocrinol. 2015;54:R119-29.

179. Arnoux JB, Verkarre V, Saint-Martin C, Montravers F, Brassier A, Valayannopoulos V, Brunelle F, Fournet JC, Robert JJ, Aigrain Y, et al, Congenital hyperinsulinism: current trends in diagnosis and therapy Orphanet J Rare Dis. 2011;6:63.

180. Arya VB, Senniappan S, Demirbilek H, Alam S, Flanagan SE, Ellard S, Hussain K. Pancreatic endocrine and exocrine function in children following near-total pancreatectomy for diffuse congenital hyperinsulinism. PLoS One. 2014;9:e98054.

181. Beltrand J, Caquard M, Arnoux JB, Laborde K, Velho G, Verkarre V, Rahier J, Brunelle F, Nihoul-Fekete C, Saudubray JM, et al. Glucose metabolism in 105 children and adolescents after pancreatectomy for congenital hyperinsulinism. Diabetes Care. 2012;35:198-203.

182. Ludwig A, Ziegenhorn K, Empting S, Meissner T, Marquard J, Holl R, Mohnike K. Glucose metabolism and neurological outcome in congenital hyperinsulinism. Semin Pediatr Surg. 2011;20:45-9.

183. Lord K, Radcliffe J, Gallagher PR, Adzick NS, Stanley CA, De Leon DD. High risk of diabetes and neurobehavioral deficits in individuals with surgically treated Hyperinsulinism. J Clin Endocrinol Metab. 2015;100:4133-9.

184. Salomon-Estebanez M, Flanagan SE, Ellard S, Rigby L, Bowden L, Mohamed Z, Nicholson J, Skae M, Hall C, Craigie R, et al. Conservatively treated congenital Hyperinsulinism (CHI) due to K-ATP channel gene mutations: reducing severity over time. Orphanet J Rare Dis. 2016;11:163.

185. Kassem SA, Ariel I, Thornton PS, Scheimberg I, Glaser B. Beta-cell proliferation and apoptosis in the developing normal human pancreas and in hyperinsulinism of infancy. Diabetes. 2000;49:1325-33.

\section{Submit your next manuscript to BioMed Central and we will help you at every step:}

- We accept pre-submission inquiries

- Our selector tool helps you to find the most relevant journal

- We provide round the clock customer support

- Convenient online submission

- Thorough peer review

- Inclusion in PubMed and all major indexing services

- Maximum visibility for your research

Submit your manuscript at www.biomedcentral.com/submit 